Os artigos dos Textos para Discussão da Escola de Economia de São Paulo da Fundação Getulio Vargas são de inteira responsabilidade dos autores e não refletem necessariamente a opinião da FGV-EESP. É permitida a reprodução total ou parcial dos artigos, desde que creditada a fonte.

Escola de Economia de São Paulo da Fundação Getulio Vargas FGV-EESP www.eesp.fgv.br 


\title{
State-controlled companies and political risk: Evidence from the 2014 Brazilian election*
}

\author{
Augusto Carvalho $\quad$ Bernardo Guimaraes ${ }^{\ddagger}$
}

November 2016

\begin{abstract}
This paper examines the vulnerability of state-controlled companies to political risk using the 2014 Brazilian election and data on stock options. In her first term as Brazilian president, Ms. Dilma Rousseff took measures that were not aligned with the objective of maximizing profits of Petrobras, the Brazilian state-controlled oil company. She was reelected president in 2014. Results show that Petrobras would be worth around $62 \%$ (USD 45 billion) more if the opposition candidate had won the election. Using our estimated reelection probabilities and stock price data, we also find that the election of Ms. Rousseff had a negative impact on the value of several companies, but the effects on Petrobras and Banco do Brasil, the state-controlled bank, were particularly strong.
\end{abstract}

KEYWORDS: election; options; political risk; minority shareholders.

Jel Classification: G13; O16; P14.

\section{Introduction}

A sizable empirical literature shows that state owned firms are usually less profitable than private companies.1 1 There are two sets of reasons for this: (i) the government might pursue objectives other than profit maximization that are aligned with its political platform; (ii) state firms might be inherently less efficient or more prone to corruption. The implication for

\footnotetext{
*We thank Alan De Genaro, Jefferson Duarte, Marcelo Fernandes, Bruno Giovannetti and seminar participants at U Sao Paulo and the Sao Paulo School of Economics - FGV for helpful comments and suggestions. We also thank Leticia Munhoz for able research assistance. Carvalho gratefully acknowledges financial support from CAPES. Guimaraes gratefully acknowledges financial support from CNPq.

${ }^{\dagger}$ Sao Paulo School of Economics - FGV, Rua Itapeva 474, 01332-000, Sao Paulo - SP, Brazil.

${ }^{\ddagger}$ Sao Paulo School of Economics - FGV, Rua Itapeva 474, 01332-000, Sao Paulo - SP, Brazil.

1 Megginson and Netter (2001) survey the empirical literature on privatization. According to the vast majority of papers in this literature, state owned firms are less profitable than private companies. For example, Boardman and Vining (1989) and Dewenter and Malatesta (2001) compare the largest private-owned and government-owned firms and find the former are, on average, significantly more profitable. La Porta and Lopez-de Silanes (1999) use data from privatized firms in Mexico and find that productivity gains are the main drivers of the increased in profits from privatization. Sapienza (2004) finds that in Italy, all else equal, state-owned banks charge lower interest rates than do privately owned banks and attributes this difference to political distortions. Using data on Indian state-owned companies, Gupta (2005) finds that partial privatization has a positive impact on profitability, productivity, and investment. An exception in this literature, highlighting the value of political connections, is Calomiris et al. (2010). They argue that in China, the benefits of political ties outweigh the efficiency costs of government shareholdings.
} 
minority shareholders is that, all else equal, state controlled firms are worth less than private companies.

This difference might depend on the incumbent government. This might be particularly important in emerging economies, where institutions are strong enough to allow for the existence of capital markets, but might fail to prevent policies that negatively affect the value of a state-controlled company for its shareholders. The implication is that state-controlled firms in emerging economies would be particularly vulnerable to political risk.

Petrobras, the Brazilian oil company, is a case in point. It is controlled by the Brazilian government, but most of its non-voting shares and a sizable part of voting shares are publicly traded. Once the largest company in Latin America, it has seen its value decline by more than $90 \%$ (in dollars) between the end of 2010 and the end of 2015. During her first term as president (between 2011 and 2014), Ms. Dilma Rousseff took several measures that were not aligned with the objective of maximizing Petrobras' profits. Would a change in government have a large impact on the stock value of Petrobras?

The 2014 Brazilian election offers us an opportunity to assess the impact of a change in government via elections on the value of a state-controlled company for its shareholders. The main contenders in the election were Ms. Rousseff and Mr. Neves, an opposition candidate identified with a pro-market platform. In a hotly contested race, Ms. Rousseff was reelected by a narrow margin. If elections can have large effects on the value of a state-controlled company, an opposition victory should be associated with a large increase in prices of Petrobras shares.

However, estimating the effect of an election on asset prices is difficult because we only observe one outcome. Additionally, election results are partially, if not completely, expected, which makes detecting these effects particularly difficult. A recent literature studies the effects of elections using the implied probabilities from prediction markets. ${ }^{2}$ However, in Brazil, as in many other countries, there is no such data: $:^{3}$

This paper uses stock options to estimate the value of Petrobras shares conditional on different election outcomes of the 2014 Brazilian presidential election. Options with different strike prices carry information about different moments of the probability distribution of the underlying asset. Hence they allow us to disentangle the probability of each election outcome, the gap in valuation and normal disturbances unrelated to the election.

We extend standard asset pricing models by including (i) a parameter to be interpreted as the gap in valuation of the asset conditional on the election winner; and (ii) a time series

\footnotetext{
${ }^{2}$ For example, Herron et al. $\sqrt{1999)}$ and $\overline{\text { Knight }}(2006)$ use data from the Iowa Electronic Markets to back out the probability of each outcome in US presidential elections, Snowberg et al. (2007) use the market-based probability of a Bush reelection in 2004 from TradeSports.com and Imai and Shelton (2011) use data from a political prediction market in Taiwan.

3 Ferraz $(2015)$ built and studied a prediction market for Brazilian elections. However, market participants used play money and there were clear arbitrage opportunities - for instance, selling all contracts the day before the election, implying a certain liability of $\$ 100$, would yield $\$ 111.7$. This market forecasted a victory by Mr. Neves.
} 
of daily probabilities reflecting the constantly changing market expectations regarding the election outcome. We first show results for the extension of the Black and Scholes model. We then include uncertainty about the effect of the election outcome. Last, we show results for the extension of the model of Heston (1993), which is our preferred specification.

In our preferred specification, Petrobras preference shares would cost $66 \%$ more had the opposition candidate been elected. In order to assess the effect of the election on the value of the company, we also need to estimate the effect of the election on the price of ordinary shares of Petrobras. These appear to be less responsive to the election results. Using the relation between the estimated probability of reelection and the ratio of preference share prices to ordinary share prices, we estimate that Petrobras would be worth $62 \%$ more in case Ms. Rousseff had lost the election. The effect is huge both in relative and in absolute terms, as it translates into a USD 45 billion difference in company valuation, around 1,85\% of Brazil's GDP in 2014. Using the Black and Scholes specification, this difference goes up to 71\%, or around USD 51 billion.

Reported results for the probabilities of each election outcome are in general agreement with the movements in presidential polls. Reassuringly, from the Election Day on, the estimates attribute probability close to 1 to a win by the elected president.

We then use our estimated probabilities of reelection to assess the effect of political risk on a variety of asset prices. We find that the election of Ms. Rousseff had a strong negative effect on the value of many companies. However, the effects on Petrobras and Banco do Brasil, the Brazilian state-controlled bank, were particularly strong.

The remainder of this introduction discusses the relation between this paper and the literature. Section 2 describes policies adopted by President Rousseff that affected the value of Petrobras during her first term in power and provides information about the 2014 Brazilian election. Section 3 explains the empirical model, describes the data and estimation and discusses the intuition for identification. Section 4 presents and discusses the results and Section 6] concludes.

\section{$1.1 \quad$ Related Literature}

This paper is related to a literature that studies the effects of elections on asset prices to gauge how different parties affect the economy. For example, Herron (2000) finds that higher interest rates and lower stock market prices were expected had the Labour Party won the British elections in 1992; Knight (2006) studies how the odds of a vitory for Bush or Gore in the 2000 American election affect the market value of politically sensitive firms and finds that policy platforms were capitalized into equity prices; Imai and Shelton (2011) show that 
share prices of Taiwanese firms with investments in the mainland responded strongly to a positive electoral outlook for the party that advocates lifting caps on cross-strait investment in mainland China; Snowberg et al. (2007) study how the Bush reelection in 2004 affected stock markets and find that electing a Republican President raises equity valuations by $2-3 \% .4$ The effects found in all these papers are much smaller than the $62-71 \%$ increase in the value of Petrobras that would arise from an opposition win in the 2014 Brazilian election.

This paper is also related to a literature that connects political risk, market volatility and uncertainty premia. Pantzalis et al. (2000) find positive abnormal returns in the weeks leading to an election in their sample of 33 countries. Brogaard and Detzel (2015), employing the uncertainty measure of Baker et al. (2016), also find that economic policy uncertainty is associated with positive abnormal returns. Using options, Kelly et al. (2016) assess the effect of political risk on asset prices studying events like summits and elections. They show that options whose lives span political events are on average $5 \%$ more expensive than otherwise similar options. Goodell and Vähämaa (2013) also find a link between stock market volatility and political uncertainty using the VIX volatility index and data from the Iowa Electronic Markets over five US presidential elections.

Previous work has explored the link between finance and politics in Brazil. Claessens et al. (2008) show that political connections affect access to bank finance in Brazil, which in turn affects stock returns. $5^{5}$ Carvalho (2014) presents evidence that BNDES, the Brazilian development bank, expands (subsidized) loans in politically attractive regions right before elections. Fernandes and Novaes (2016) study the role of the Brazilian government as a large shareholder in recent years. They show that government activism lowered the value of minority shareholders' voting rights, which harmed minority shareholders in Brazil.

A branch of the literature has emphasized the effect of slow-moving institutional and legal factors on the rights of minority shareholders.6 This paper asks whether changes through elections can also have a large impact on the value of a state-controlled company. $]^{7}$

One distinguishable feature of our paper is the use of stock options to estimate both the

\footnotetext{
${ }^{4}$ There is also a literature on the relation between stock returns and the party in power (see, e.g., Santa-Clara and Valkanov (2003) and Leblang and Mukherjee (2005)).

${ }^{5} \mathrm{~A}$ growing empirical literature examines the role of political connections. For example, Fisman (2001) estimates the value of political connections in Indonesia by assessing the effect of news about President Suharto's health on firms with differing degrees of political exposure; Johnson and Mitton (2003) argue that Malaysian capital controls provided a screen behind which favored firms could be supported; Leuz and Oberholzer-Gee (2006) argue that foreign securities and close political connections are substitutes; Ferguson and Voth (2008) assess the value of political connections in Nazi Germany; Acemoglu et al. (2015) use data from Egypt to show that street protests are associated with lower stock market valuations for firms connected to the group in power relative to non-connected firms. These papers study a particular country, but there is also cross country work on political connections. Faccio (2006) uses data from many firms in 47 countries and finds significant abnormal returns for establishing political connections. Faccio et al. (2006) show evidence that politically connected firms are more likely to be bailed out.

${ }^{6}$ See La Porta et al. (2000 2002) and a literature that followed.

${ }^{7}$ There is a related discussion in development economics about the relative roles of institutions and macroeconomic policies (see, e.g., Henry and Miller (2009)).
} 
probability of each outcome and their effects on the value of the company. Data on options have been used to extract information about the probability distribution of assets in a variety of ways. One branch of this literature builds on Breeden and Litzenberger (1978) to extract the risk neutral densities of an asset. This method has been used to back out the probability distribution of assets in foreign exchange markets (e.g., Campa and Chang (1996) and Campa et al. (2002)), bond markets (e.g., Söderlind and Svensson (1997)) and stock markets (e.g. AïSahalia and Lo (1998)).

This paper is closer to the branch of this literature that employs extentions of the models of Black and Scholes (1973), Merton (1976), Heston (1993) and Hull and White (1987) to back out parameters that characterize the probability distribution of an asset. This methodology has been applied to study whether a stock market crash was somewhat expected (Bates (1991)), to estimate realignment probabilities of European exchange rates (Malz (1996), Bates (1996)), to understand pricing of foreign currency options (Melino and Turnbull (1990)), to infer expectations about equity markets (Bakshi et al. (1997) and Bates (2000), among other things.

This paper is particularly related to work that uses options to study the impact of scheduled events on asset prices. Beber and Brandt (2006) show that macroeconomic announcements reduce the implied volatility of US Treasury bond future prices. Patell and Wolfson (1979) study the effects of earnings announcements by investigating how the implied Black-Scholes volatility behaves around announcement dates. Our methodology is closer to Dubinsky and Johannes (2006), who use a simple diffusion model and data on options to disentangle the uncertainty over the information revealed on earnings dates from normal day-to-day volatility. Our empirical model is different because we study an event with a binary outcome.

Few papers use options to study the effect of elections. Besides Kelly et al. (2016) and Goodell and Vähämaa (2013), Gemmill (1992) studies the 1987 British election and finds evidence of inefficiency in the option market and Leahy and Thomas (1996) investigate how a referendum in Canada affected expectations about the exchange rate using a mixture of log-normal distributions.

\section{Background}

\subsection{Petrobras under the government of Ms. Rousseff}

President Dilma Rousseff and Petrobras have grabbed newspaper headlines in the whole world for what has been considered the biggest corruption scandal in Brazilian history, the so called "Big Oily". From the point of view of minority shareholders, the key implication of this 
corruption scheme is that a lot of money was diverted from the company 8

Corruption is, however, only one among the several ways through which actions undertaken by the government of Ms. Rousseff were detrimental to Petrobras' minority shareholders $9^{9}$ In fact, much of the problem stems from conflicting interests between the main shareholder, the government, and minority shareholders.

The 'Law of local content' determined that equipment bought by Petrobras had to contain a certain amount of nationally produced components 10 As an example, in a purchase of 20 cranes for off-shore oil extraction, the first one to be delivered (in 2012) had a requirement of $20 \%$ of national content, while the last one had a requirement of $65 \%$ of national content. This protectionist measure was justified as part of an effort to foster industrialization in Brazil. Whatever one thinks of this kind of development policy, the fact is that Petrobras was footing the bill, as the local-content constraint was clearly binding.

In another example of government action costly to Petrobras, the increase in oil price for consumers was substantially below inflation in that period. In Brazil, a substantial share of prices is controlled by the government. During this period, inflation had overshot the target and the government attempted to reduce the official rate by keeping controlled prices down ${ }^{11}$ Again, this policy was detrimental to the profitability of Petrobras.

Petrobras' shares are widely dispersed across minority shareholders. Owing to one particular feature of Brazilian labour regulations, even those who do not regularly participate in the stock market might own Petrobras shares. Part of the payments from employers to employees (around $8 \%$ of the wage) is deposited into an account that an employee can only access when she is fired, retires, or under some special conditions (e.g., buying a house). Over this century, this account has been remunerated at negative real interest rates (for example, in 2015, nominal interest rates on this account were below $5 \%$, while inflation was above $10 \%$ and interest rates on government bonds were around 14\%). Sometimes the government allows people to use resources from this account to buy shares of Petrobras. Hence the set of minority shareholders of Petrobras is very large and heterogeneous, including all groups except the very poor, who do not work in the formal sector, do not own shares of any company, but are not directly affected by lower oil prices either.

\footnotetext{
${ }^{8}$ See, e.g., The Economist, January $3^{r d}, 2015$, "The big oily". The report notes that "minority shareholders are furious".

${ }^{9}$ That is not to say that corruption, in the broad sense of the word, was not very costly. Some large and unsuccessful investment decisions appear to have been politically motivated.

${ }^{10}$ Law 12.351 from December $22^{\text {nd }}, 2010$

${ }^{11}$ Brazil employs an inflation target regime. The center of the target is $4.5 \%$ a year and the ceiling is $6.5 \%$. Inflation in this period was just below $6.5 \%$ owing to a very low inflation of government-controlled prices.
} 


\subsection{The election}

The presidential election in Brazil is held in two rounds. If no candidate achieves $50 \%$ of the votes in the first ballot, there is a second ballot three weeks after the first one involving only the two most voted candidates in the first round.

In the first ballot, out of the 11 total canditates, three held over $95 \%$ of the valid votes: ${ }^{12}$ Ms. Dilma Rousseff from the Worker's Party (PT) came first, Mr. Aecio Neves from the Brazilian Social-Democratic Party (PSDB) came second and Ms. Marina Silva from the Brazilian Socialist Party (PSB) came third.

The second ballot between Ms. Rousseff and Mr. Neves was one of the closest presidential elections in Brazilian history. In the first two weeks after the first ballot, opinion polls showed no statistically-significant advantage for either candidate. The fierceness of the race was reflected by the overall tense political climate of the country. On October $26^{\text {th }}$, the drama came to a closing with Ms. Rousseff being reelected president of Brazil, beating Mr. Neves $51.64 \%$ to $48.36 \%$.

There is plenty of anecdotal evidence pointing to the effect of expectations about the presidential election on Petrobras' valuation. Five weeks before the first ballot, Ms. Silva was seen as the front runner.13 At that point, the price of Petrobras' shares reached more than BRL 24. A month later, with opinion polls showing Ms. Rousseff was clearly ahead of the opposition candidates and even had a chance to reach the $50 \%$ bar in the first ballot, shares of Petrobras would be traded at below BRL 16. The biggest overnight price increase happened right after the first ballot, because Ms. Rousseff did worse than expected and Mr. Neves did substantially better than predicted by polls.

On Monday after the second ballot, with the reelection of Ms. Rousseff confirmed, Petrobras shares went down by $12 \%$. Since at that point Ms. Rousseff was the favorite to win, the key question is what would have happened to the price of Petrobras had Mr. Neves won the election.

\section{Methodology}

\subsection{The empirical model}

We augment an asset diffusion process by assuming there are two possible election outcomes, High and Low. Denote by $S_{\text {high }}(t)$ and $S_{\text {low }}(t)$ the asset value conditional on outcomes High

\footnotetext{
${ }^{12}$ 'Valid votes' include votes to all candidates but do not include blank and null votes.

${ }^{13}$ The presidential candidate from PSB was Mr. Eduardo Campos. However, he died in a plane crash in August $14^{\text {th }}$, amidst the presidential campaign. Ms. Marina Silva, PSB's coalition vice-president candidate, stepped up to take Mr. Campos' place as candidate for presidency and was eloquently supported.
} 
and Low, respectively, and define $\Delta$ as following:

$$
\Delta \doteq \frac{S_{\text {high }}(t)}{S_{\text {low }}(t)}
$$

In our baseline estimation, $\Delta$ is assumed to be constant, reflecting the idea that market expectations about each candidate's effect on the value of Petrobras are not expected to change significantly in only 3 weeks. In Appendix C, we show that the results do not rely on this assumption.

The asset value conditional on a low outcome follows a diffusion process. We estimate the model under three different assumptions for the distribution of $S_{l o w}(t)$ : the Black and Scholes model, a simple extension of Black and Scholes with an election-day jump and the Heston model.

The event defining which outcome is chosen is the second round of the election, which will happen at time $\bar{T}$. For $t<\bar{T}$, the probability of outcome Low is given by $\theta(t)$, with $0 \leq \theta(t) \leq 1$ for all $t<\bar{T}$ ). For any $\tilde{t}>t$, we have that $\mathbb{E}_{t}[\theta(\tilde{t})]=\theta(t)$ (probabilities are martingale) and shocks to $\theta(t)$ and $S_{\text {low }}(t)$ are uncorrelated.14

As the bulk of the literature, this paper uses options to retrieve the 'risk-neutral densities'. However, here, the assumption of risk neutrality is less important. In the extension of the Black and Scholes model, the assumption of risk neutrality could be made without loss of generality. ${ }^{15}$ Since there are only two possible states (High and Low), it is possible to construct a risk-free portfolio with a small number of options and the standard argument for the irrelevance of risk considerations goes through. In case of the other models, there is still some volatility risk, hence attitudes toward risk could still be relevant for option prices. However, the effect of risk considerations on securities prices should be mitigated by foreign investors that trade Petrobras shares in the Brazilian and in the American stock markets it is reasonable to assume that this Brazilian-specific volatility risk is diversifiable for foreign investors.

The observed stock price $S^{*}(t)$ is thus given by:

$$
S^{*}(t)=\theta(t) S_{\text {low }}(t)+(1-\theta(t)) S_{\text {high }}(t)
$$

Denote by $\tilde{C}(S)$ the price of a call option for an asset with spot price $S$ that follows the

\footnotetext{
${ }^{14}$ One could argue that positive shocks to the world economy or to oil prices could raise both $S_{\text {low }}(t)$ and the probability of reelection. In this case, conditional on the incumbent win, $S_{l o w}(t)$ would be larger. However, since the Low state corresponds to an incumbent win, that would reduce the distance between outcomes. The observable difference in the expected value of Petrobras in both states would thus be smaller than $\Delta$, leading to a downward bias in our estimates.

${ }^{15}$ Without the assumption of risk neutrality, we would not get the expression for $S^{*}(t)$ in $\sqrt{1}$, hence a time series for both $S_{\text {low }}(t)$ and $S_{\text {high }}(t)$ would have to be estimated. However, estimating the model in this way yields very similar results to those presented in Section 4.1
} 
assumed diffusion process (given the strike price, the time to maturity and the interest rate). Then the price of a call in this model $C\left(S_{t}^{*}\right)$ is given by: ${ }^{16}$

$$
C\left(S_{t}^{*}\right)=\theta(t) \tilde{C}\left(S_{\text {low }}(t)\right)+(1-\theta(t)) \tilde{C}\left(S_{\text {high }}(t)\right)
$$

Combining (1) and (2), we get an expression for the price of a call that depends only on the observed stock price $S^{*}(t)$ and parameters of the model: ${ }^{17}$

$$
C\left(S_{t}^{*}\right)=\theta(t) \tilde{C}\left(\frac{S_{t}^{*}}{\theta(t)+(1-\theta(t)) \Delta}\right)+(1-\theta(t)) \tilde{C}\left(\frac{S_{t}^{*} \Delta}{\theta(t)+(1-\theta(t)) \Delta}\right)
$$

The formula for $\tilde{C}$ depends on the diffusion process considered, which will be discussed in Section 4

\subsection{Data and estimation}

The Petrobras' stock options employed in this work are negotiated at the Sao Paulo's stock exchange, BM\&FBovespa. 18 Stock options traded in BM\&FBovespa mature on Monday in the $3^{\text {rd }}$ week of each month. We use daily data on options with maturity on November $17^{\text {th }}$, the first maturity date following the election. Our date base comprises 2,349 data points in the 6 -week period from October $6^{\text {th }}$ to November $14^{\text {th }}$. The first 3 weeks (15 days) of the sample cover the period between the first and the second ballots, while the last 3 weeks of the sample occur after the second ballot.

The options in our data refer to preference shares of Petrobras, that have no voting rights 19 All puts are European. There are both American and European calls in our sample, but since the strike price is adjusted to offset the effect of dividends, the well known result in Merton (1973) shows either type of call should be worth the same.20

Table 1 shows the sample comprises a large range of strike prices and for many of them we have data for most dates, especially before the election. That is important for the identification of $\Delta$. As shown in Table 1, trade on options with large strike prices is severely reduced after the election, suggesting that Ms. Rousseff's victory made clear those strike prices would not be reached. Indeed, trade on options with low strike price increases after the election.

The value of Petrobras is distributed among 5.6 billion outstanding preference shares and

\footnotetext{
${ }^{16} \mathrm{~A}$ derivation is presented in Appendix A

${ }^{17}$ The formula for an European put option is analogous.

${ }^{18}$ Petrobras represents a significant share of the Brazilian stock market index (around $13 \%$ of the index at the beginning of 2014 and around $8 \%$ of the index at the beginning of 2015) and much of the market for stock options.

${ }^{19}$ Ordinary shares (with voting rights) are also traded at BM\&FBovespa, but the market for options on these shares is much thiner.

${ }^{20}$ Indeed, there is a negligible amount of early exercises in the week before maturity.
} 


\begin{tabular}{|c|c|c|c|c|c|c|c|c|}
\hline \multirow[b]{3}{*}{ Strike } & \multicolumn{4}{|c|}{ \# of dates the option was traded } & \multicolumn{4}{|c|}{ Traded volume (Brazilian Reais) } \\
\hline & \multicolumn{2}{|c|}{ Before the election } & \multicolumn{2}{|c|}{ After the election } & \multicolumn{2}{|c|}{ Before the election } & \multicolumn{2}{|c|}{ After the election } \\
\hline & Call & Put & Call & Put & Call & Put & Call & Put \\
\hline 9.16 & 0 & 1 & 0 & 3 & - & 64 & - & 68 \\
\hline 10.16 & 0 & 1 & 2 & 11 & - & 32 & 73 & 41 \\
\hline 11.16 & 7 & 6 & 15 & 14 & 37,374 & 11,791 & 38,073 & 6,061 \\
\hline 11.66 & 0 & 0 & 0 & 3 & - & - & - & 208 \\
\hline 12.16 & 6 & 7 & 15 & 15 & 6,262 & 22,637 & 197,851 & 21,028 \\
\hline 12.66 & 0 & 0 & 5 & 10 & - & - & 3,928 & 7,703 \\
\hline 13.16 & 15 & 15 & 15 & 15 & 102,933 & 74,611 & $1,135,558$ & 150,631 \\
\hline 13.66 & 0 & 0 & 12 & 11 & - & - & 11,800 & 10,441 \\
\hline 13.91 & 7 & 11 & 15 & 15 & 2,013 & 14,992 & 45,345 & 33,683 \\
\hline 14.16 & 15 & 15 & 15 & 15 & 157,759 & 125,060 & $2,522,195$ & 405,750 \\
\hline 14.66 & 4 & 11 & 15 & 15 & 2,617 & 40,950 & 99,551 & 48,429 \\
\hline 14.91 & 14 & 15 & 15 & 15 & 77,282 & 125,793 & $1,504,090$ & 192,109 \\
\hline 15.16 & 9 & 15 & 15 & 15 & 125,707 & 67,426 & 385,620 & 63,358 \\
\hline 15.41 & 9 & 12 & 15 & 14 & 51,891 & 18,876 & 21,222 & 21,825 \\
\hline 15.66 & 10 & 15 & 15 & 15 & 91,878 & 23,618 & 75,713 & 38,270 \\
\hline 16.16 & 15 & 15 & 15 & 15 & 364,776 & 139,426 & 224,598 & 126,029 \\
\hline 16.41 & 12 & 14 & 14 & 14 & 17,042 & 34,191 & 7,032 & 12,449 \\
\hline 16.66 & 15 & 15 & 15 & 15 & 414,821 & 170,779 & 396,466 & 92,426 \\
\hline 17.16 & 13 & 15 & 15 & 15 & 260,268 & 369,184 & 101,941 & 418,363 \\
\hline 17.41 & 7 & 14 & 13 & 13 & 9,123 & 46,113 & 1,699 & 6,201 \\
\hline 17.66 & 15 & 15 & 15 & 15 & 238,511 & 149,882 & 79,363 & 92,673 \\
\hline 17.91 & 13 & 15 & 13 & 6 & 8,447 & 15,990 & 744 & 9,108 \\
\hline 18.16 & 15 & 15 & 15 & 15 & 913,277 & 149,228 & 109,425 & 261,700 \\
\hline 18.41 & 12 & 15 & 15 & 11 & 43,637 & 96,704 & 821 & 22,265 \\
\hline 18.66 & 15 & 15 & 14 & 14 & 199,465 & 90,910 & 5,607 & 506,990 \\
\hline 19.16 & 15 & 15 & 15 & 15 & 826,847 & 149,480 & 37,132 & 80,966 \\
\hline 19.41 & 15 & 15 & 13 & 10 & 15,063 & 34,907 & 765 & 16,849 \\
\hline 19.66 & 15 & 14 & 12 & 11 & 69,959 & 29,422 & 741 & 134,909 \\
\hline 19.91 & 15 & 13 & 11 & 6 & 15,319 & 13,097 & 122 & 1,257 \\
\hline 20.16 & 15 & 15 & 15 & 14 & $1,556,305$ & 121,015 & 28,453 & 57,766 \\
\hline 20.41 & 7 & 5 & 4 & 1 & 12,280 & 5,777 & 43 & 365 \\
\hline 20.66 & 15 & 15 & 13 & 6 & 285,750 & 45,673 & 1,077 & 6,628 \\
\hline 20.91 & 13 & 13 & 3 & 4 & 18,025 & 28,195 & 40 & 6,231 \\
\hline 21.16 & 15 & 15 & 14 & 11 & $1,560,520$ & 84,329 & 20,772 & 16,130 \\
\hline 21.41 & 8 & 7 & 7 & 3 & 9,203 & 19,728 & 20 & 161 \\
\hline 21.66 & 15 & 15 & 13 & 7 & 198,740 & 146,649 & 374 & 6,289 \\
\hline 21.91 & 11 & 9 & 4 & 1 & 18,156 & 61,117 & 76 & 1,135 \\
\hline 22.16 & 15 & 15 & 14 & 14 & $2,845,996$ & 68,004 & 21,904 & 36,408 \\
\hline 22.41 & 15 & 10 & 8 & 5 & 746,620 & 7,038 & 432 & 1,174 \\
\hline 22.66 & 15 & 11 & 6 & 2 & 812,367 & 7,847 & 983 & 831 \\
\hline 22.91 & 14 & 6 & 5 & 1 & 15,699 & 15,548 & 209 & 1,227 \\
\hline 23.16 & 15 & 14 & 13 & 5 & $3,349,991$ & 33,735 & 9,050 & 1,838 \\
\hline 23.41 & 15 & 2 & 5 & 0 & 10,337 & 133 & 66 & - \\
\hline 23.66 & 15 & 3 & 5 & 3 & 969,741 & 347 & 1,052 & 259 \\
\hline 24.16 & 15 & 11 & 13 & 5 & $1,975,475$ & 11,571 & 4,502 & 3,619 \\
\hline 24.66 & 15 & 1 & 6 & 0 & 697,742 & 5 & 372 & - \\
\hline 25.16 & 15 & 2 & 12 & 2 & $1,184,860$ & 91 & 1,598 & 231 \\
\hline 25.66 & 15 & 1 & 3 & 0 & 68,993 & 186 & 32 & - \\
\hline 26.16 & 15 & 10 & 9 & 1 & 526,509 & 52,634 & 591 & 2,455 \\
\hline 26.41 & 15 & 0 & 3 & 1 & 11,100 & - & 24 & 26 \\
\hline 26.66 & 15 & 0 & 8 & 0 & 611,476 & - & 417 & - \\
\hline 27.16 & 15 & 0 & 8 & 0 & 702,970 & - & 712 & - \\
\hline 27.66 & 15 & 0 & 2 & 0 & 17,297 & - & 7 & - \\
\hline 28.16 & 15 & 0 & 9 & 0 & 249,254 & - & 119 & - \\
\hline 28.66 & 15 & 0 & 2 & 0 & 6,471 & - & 8 & - \\
\hline 29.16 & 15 & 0 & 5 & 0 & 94,835 & - & 107 & - \\
\hline 29.66 & 15 & 0 & 1 & 0 & 6,989 & - & 33 & - \\
\hline 30.16 & 15 & 1 & 10 & 2 & 193,246 & 872 & 375 & 2,045 \\
\hline 30.66 & 5 & 0 & 1 & 0 & 639 & - & 55 & - \\
\hline 31.16 & 15 & 0 & 8 & 0 & 114,364 & - & 143 & - \\
\hline 32.16 & 13 & 0 & 1 & 0 & 16,089 & - & 75 & - \\
\hline 33.16 & 11 & 0 & 1 & 0 & 2,350 & - & 14 & - \\
\hline 33.91 & 15 & 1 & 5 & 1 & 12,753 & 8,312 & 15 & 681 \\
\hline 34.16 & 11 & 0 & 1 & 0 & 1,707 & - & 11 & - \\
\hline 35.16 & 13 & 0 & 1 & 0 & 2,319 & - & 63 & - \\
\hline 36.16 & 1 & 0 & 1 & 0 & 2 & - & 0 & - \\
\hline
\end{tabular}

Table 1: Data description 
7.44 billion ordinary shares. On Monday October $27^{\text {th }}$, right after the election, the closing price of preference shares was BRL 14.29, while the closing price of ordinary shares was BRL 13.92 ${ }^{21}$ Hence, Petrobras was worth BRL 183.6 billion on the first date after the 2014 Brazilian election, which was then equivalent to USD 72.45 billion (using the exchange rate from October $\left.27^{\text {th }}\right){ }^{22}$

Each observation $i$ corresponds to an option with a certain strike price in a given date. We have daily information on the price of the last trade for each option. For the spot price of Petrobras, we used the price of the last trade at each date. For the interest rate, we used the interbank short-term rate (CDI).

Define $\epsilon_{i}$ as the difference between the observed and the theoretical option prices

$$
\epsilon_{i} \doteq C^{o b s}\left(S_{t}^{*}\right)-C\left(S_{t}^{*}\right)
$$

where $C\left(S_{t}^{*}\right)^{\text {obs }}$ is the observed option price. The estimates of $\Delta$, reelection probabilities $\theta(t)$ and parameters of diffusion models are found by non linear least squares.

\subsection{Discussion on identification}

There are many combinations of parameters that will result in an observed option price. However, options with different strike prices carry information about different moments of the price distribution, hence they allow us to identify $\Delta$ and $\theta$. Figure 1 helps understanding the intuition for identification showing how the probability distribution of stock prices is affected by changes in $\Delta, \theta$ and a parameter that affects the standard deviation of $S_{l o w}$, denoted by $\sigma$.

An increase in $\sigma$ spreads the density function, as illustrated in the top panel of Figure 1. A larger $\sigma$ corresponds to more or larger shocks regarding the company business that are unrelated to the result of the election. Changes in world oil prices, news about success or failure of the company's projects are examples of such shocks.

An increase in $\Delta$, corresponding to a larger increase in the value of Petrobras conditional on the High State, shifts the right side of the distribution of $S$ further to the right, driving the peaks farther away, as shown in the medium panel of Figure 1.

Last, the probability of the Low state $\theta$ moves according to news from polls, newspapers, debates, etc. Shocks to $\theta$ change the relative mass under each peak. An increase in $\theta$ increases the odds of a lower realization of $S$, as illustrated in the bottom panel of Figure 1.

\footnotetext{
${ }^{21}$ The codes for preference and ordinary shares at BM\&FBovespa are PETR4 and PETR3, respectively.

${ }^{22}$ For comparison, in 2014, market capitalization of Exxon Mobil was USD 416 billion, Royal Dutch Shell was worth USD 238 billion and British Petroleum was worth USD 156 billion.
} 



Figure 1: Effects of $\sigma, \Delta$ and $\theta$ on the probability density function 
Now consider a put with a low strike price and a call with a high strike price. An increase in $\sigma$ raises the price of both. An increase in $\Delta$ raises the price of the out-of-the-money call but does not affect the value of the low-strike put. In turn, an increase in $\theta$ raises the value of the put and reduces the price of the call.

A close election race helps us to identify $\Delta$. If $\theta$ is close to 0 or 1 , one of the outcomes will have little effect on option prices. In contrast, when $\theta \sim 1-\theta$, the probability density for the asset will be very different from the usual single-peaked distribution. Similarly, a large gap in valuation helps us to identify $\theta$. If $\Delta$ is small, changes in $\theta$ will also have little effect in option prices, making it harder to detect the change in mass under different peaks of the distribution.

This example considers a simple lognormal distribution of stock prices, but the message applies to more general diffusion processes. The key here is that changes in other parameters of the model affect the probability distribution of $s$ regardless of the election outcome. For example, the parameters of the Heston model affect how thick the tails of the distribution are, but do not shift the right side of the distribution (like $\Delta$ ) and do not change the relative mass under each peak (like $\theta$ ).

\section{Results}

This section starts showing results for the simple Black and Scholes case. It then explains why more elaborate models might be more appropriate and shows results for the variation of the Black and Scholes model with an election day jump and for our preferred specification, the extension of the Heston diffusion model.

\subsection{The Black and Scholes model}

The asset value conditional on each outcome follows a Geometric Brownian motion. Hence

$$
\frac{d S_{\text {low }}(t)}{S_{\text {low }}(t)}=\mu d t+\sigma d W_{t},
$$

where $\sigma$ is a positive constant. We refer to the original paper for the expression for an option

price, which is the formula for $\tilde{C}$ in this case. Plugging this formula into (3) yields the expression for $C\left(S_{t}^{*}\right)$ that generates the residuals using (4).

Besides a time series for $\theta(t)$ and $\Delta$, there is just one parameter in the model, the volatility $\sigma$.

The main objective of the paper is to estimate $\Delta$, which is shown in Table 2 . 


\begin{tabular}{|c|c|c|}
\hline & estimate & std error \\
\hline$\Delta$ & $\mathbf{1 . 7 5 6}$ & 0.004 \\
\hline$\sigma$ & 0.464 & 0.006 \\
\hline
\end{tabular}

Table 2: Estimated volatility and valuation gap, using the Black-Scholes diffusion model for $S_{l o w}(t)$.

According to the results, preference shares of Petrobras would be worth BRL 25.09, or around $75 \%$ more had Ms Rousseff lost the election. As shown in Appendix B, the ratio of the preference share price to the ordinary share price appears to be negatively related with the probability of reelection $\theta$. Using a simple linear regression to estimate the counterfactual ratio of the preference share price to the ordinary share price, we estimate that ordinary shares of Petrobras would be worth BRL 23.26, or around $67 \%$ more in case of an opposition victory.

These counterfactual share prices imply an election cost of USD 51.3 billion (BRL 130 billion) as the estimated counterfactual value of Petrobras is USD 123.7 billion (BRL 313.6 billion). According to these estimates, Petrobras would be worth around $71 \%$ more if Ms. Rousseff had lost the election.23

The obtained estimate for $\sigma$ is not far but a bit larger than what is usually found for the volatility of Petrobras in normal times.

The estimates for the probability of the Low regime $\theta(t)$ and the implied shadow stock prices $S_{\text {high }}(t)$ and $S_{\text {low }}(t)$ are shown in Table $3{ }^{24}$ The table shows estimates for the three weeks between the first and second rounds and for the three weeks that followed the reelection of Ms. Rousseff.

The second round of the presidential election was held on Sunday October $26^{\text {th }}$ and the outcome was known in the same day by $8 \mathrm{pm}$. Reassuringly, all estimates of $\theta(t)$ after election day are equal or very close to $100 \%$. Besides working as a sanity test of the model, this allows us to identify the reelection of Ms. Rousseff as the outcome associated with the Low state.

The estimates for the probability of reelection are plot in Figure 2. The first round was much closer than expected, with the incumbent Ms. Dilma Rousseff beating Mr. Aecio Neves by 8 percentage points ( $41.59 \%$ to $33.55 \%)$. Ms. Marina Silva came in third place, with $21.32 \%$ of the votes. Since most of her voters were expected to shift their support to Mr. Neves (which indeed happened), this promised to be the closest presidential race in several

\footnotetext{
${ }^{23}$ An opposition win was also expected to boost the value of the Brazilian currency, which means the election cost in dollars was even larger.

${ }^{24}$ All prices in the table are shown in Brazilian Reais (BRL).
} 


\begin{tabular}{|c|c|c|c|c|c|}
\hline Date & $\theta$ & std error & $\mathrm{S}^{*}$ & $\mathrm{~S}^{\text {low }}$ & $\mathrm{S}^{\text {high }}$ \\
\hline Oct-06 & 0.33 & 0.010 & 20.39 & 13.52 & 23.73 \\
\hline Oct-07 & 0.35 & 0.010 & 21.21 & 14.19 & 24.91 \\
\hline Oct-08 & 0.55 & 0.016 & 20.85 & 15.56 & 27.32 \\
\hline Oct-09 & 0.51 & 0.015 & 21.20 & 15.43 & 27.09 \\
\hline Oct-10 & 0.53 & 0.014 & 20.02 & 14.76 & 25.91 \\
\hline Oct-13 & 0.44 & 0.011 & 22.13 & 15.55 & 27.29 \\
\hline Oct-14 & 0.45 & 0.011 & 21.65 & 15.32 & 26.90 \\
\hline Oct-15 & 0.40 & 0.009 & 20.15 & 13.83 & 24.29 \\
\hline Oct-16 & 0.40 & 0.009 & 18.65 & 12.83 & 22.53 \\
\hline Oct-17 & 0.48 & 0.011 & 19.09 & 13.70 & 24.06 \\
\hline Oct-20 & 0.56 & 0.013 & 17.92 & 13.44 & 23.59 \\
\hline Oct-21 & 0.72 & 0.010 & 16.68 & 13.77 & 24.18 \\
\hline Oct-22 & 0.72 & 0.010 & 16.61 & 13.70 & 24.05 \\
\hline Oct-23 & 0.84 & 0.007 & 15.41 & 13.71 & 24.07 \\
\hline Oct-24 & 0.66 & 0.013 & 16.30 & 13.01 & 22.83 \\
\hline Oct-27 & 0.99 & 0.003 & 14.29 & 14.22 & 24.96 \\
\hline Oct-28 & 0.99 & 0.003 & 15.03 & 14.88 & 26.13 \\
\hline Oct-29 & 1.00 & 0.004 & 14.02 & 14.02 & 24.61 \\
\hline Oct-30 & 1.00 & 0.003 & 14.32 & 14.32 & 25.14 \\
\hline Oct-31 & 0.99 & 0.004 & 15.28 & 15.14 & 26.58 \\
\hline Nov-03 & 0.99 & 0.003 & 14.85 & 14.74 & 25.87 \\
\hline Nov-04 & 0.98 & 0.003 & 14.82 & 14.61 & 25.66 \\
\hline Nov-05 & 1.00 & 0.003 & 14.40 & 14.40 & 25.28 \\
\hline Nov-06 & 1.00 & 0.004 & 14.06 & 14.02 & 24.61 \\
\hline Nov-07 & 1.00 & 0.003 & 14.27 & 14.27 & 25.05 \\
\hline Nov-10 & 1.00 & 0.003 & 13.98 & 13.98 & 24.54 \\
\hline Nov-11 & 0.99 & 0.004 & 14.00 & 13.93 & 24.46 \\
\hline Nov-12 & 1.00 & 0.003 & 14.11 & 14.11 & 24.77 \\
\hline Nov-13 & 1.00 & 0.003 & 13.60 & 13.60 & 23.88 \\
\hline Nov-14 & 1.00 & 0.003 & 13.20 & 13.18 & 23.14 \\
\hline
\end{tabular}

Table 3: Estimated market probability of Ms. Rousseff's reelection, using the Black-Scholes diffusion model for $S_{\text {low }}(t)$.

decades in Brazil.

In the first two weeks, the estimated probability of reelection oscilates between $40 \%$ and $60 \%$. With both candidates virtually tied in opinion polls, the race could go either way. On Monday October $20^{t h}$, opinion polls started to show Ms. Rousseff ahead by a small margin. 


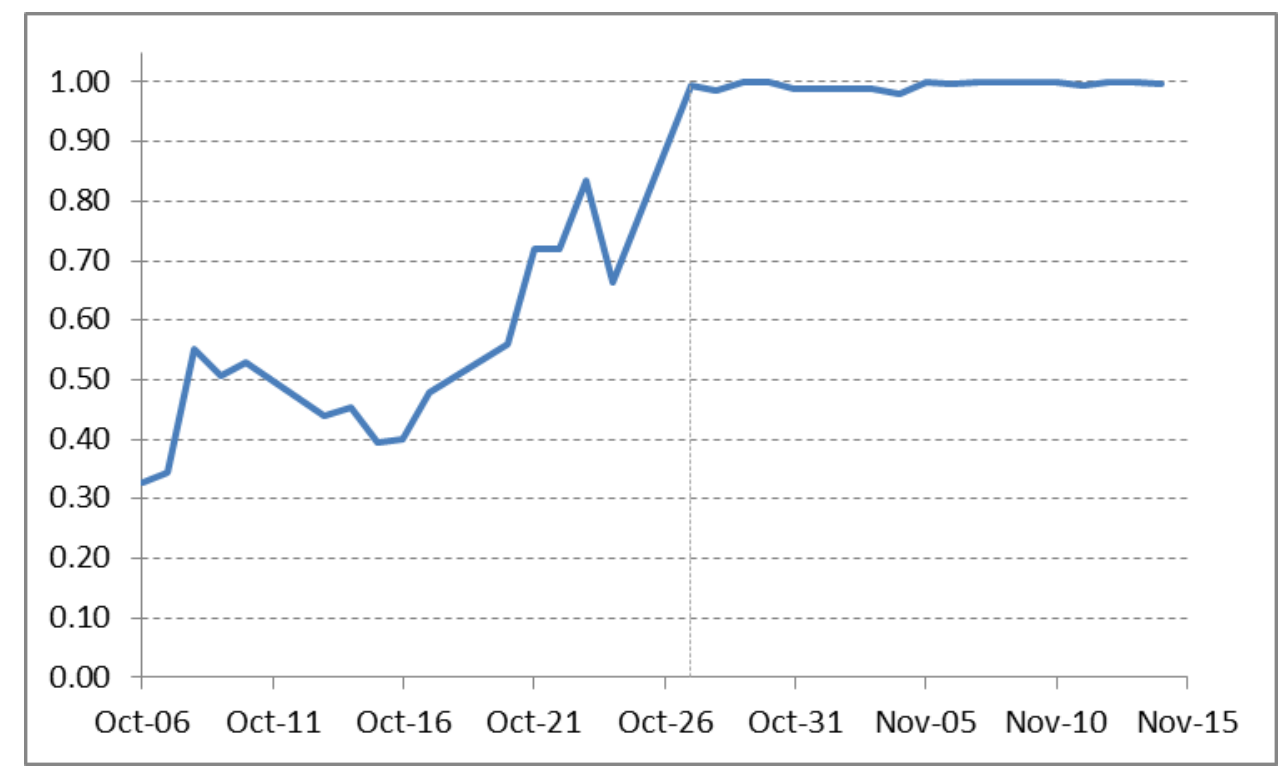

Figure 2: Estimated market probability of Ms. Rousseff's reelection, using the Black-Scholes diffusion model for $S_{\text {low }}(t)$. The dashed vertical line indicates the first trading day after Election Day.

On Thursday October $23^{r d}$, the two main polling institutes (Ibope and Datafolha) show her winning by $52 \%$ to $48 \%$ and $53 \%$ to $47 \%$, respectively. Our estimate of the probability of reelection reaches $84 \%$ on that day. Polls released on Friday showed a slight reduction in Ms. Rousseff advantage, setting a tense grand finale to a thrilling election. On Sunday October $26^{\text {th }}$, the race came to a closing with Ms. Rousseff being reelected president of Brazil, beating Mr. Neves $51.64 \%$ to $48.36 \%$.

Figure 3 shows the shadow stock prices $S_{\text {low }}(t)$ and $S_{\text {high }}(t)$ together with the observed spot price $S^{*}(t)$. The picture shows a large drop in the observed stock price, from around BRL 22 to BRL 16 between October $13^{\text {th }}$ and October $24^{\text {th }}$. The initial drop reflects a fall in $S_{\text {low }}(t)$, but most of it is explained by an increase in the probability of reelection.

On Oct-27, in the aftermath of the election, the closing price of a share of Petrobras was BRL 14.29 after reaching a minimum value of BRL 13.76. However, the estimate for $S_{\text {low }}(t)$ on Oct-24 was only BRL 13.01 (Table 3). It is likely that agents did not know how exactly the market would react to the election results owing to: (i) uncertainty about others' assessment of $\Delta$ and (ii) uncertainty about the next government policies. On the first trading day after the election, the first kind of uncertainty and, arguably, some of the second kind would be solved. ${ }^{25}$ In the next Section, we incorporate this in the model.

\footnotetext{
${ }^{25}$ Indeed, newspapers on Oct-27 had rumours that Ms. Rousseff would choose a market-friendly Minister of Finance. Weeks later, this rumours would be confirmed, as Mr. Joaquim Levy, a banker with a PhD in Economics from U Chicago would be
} 


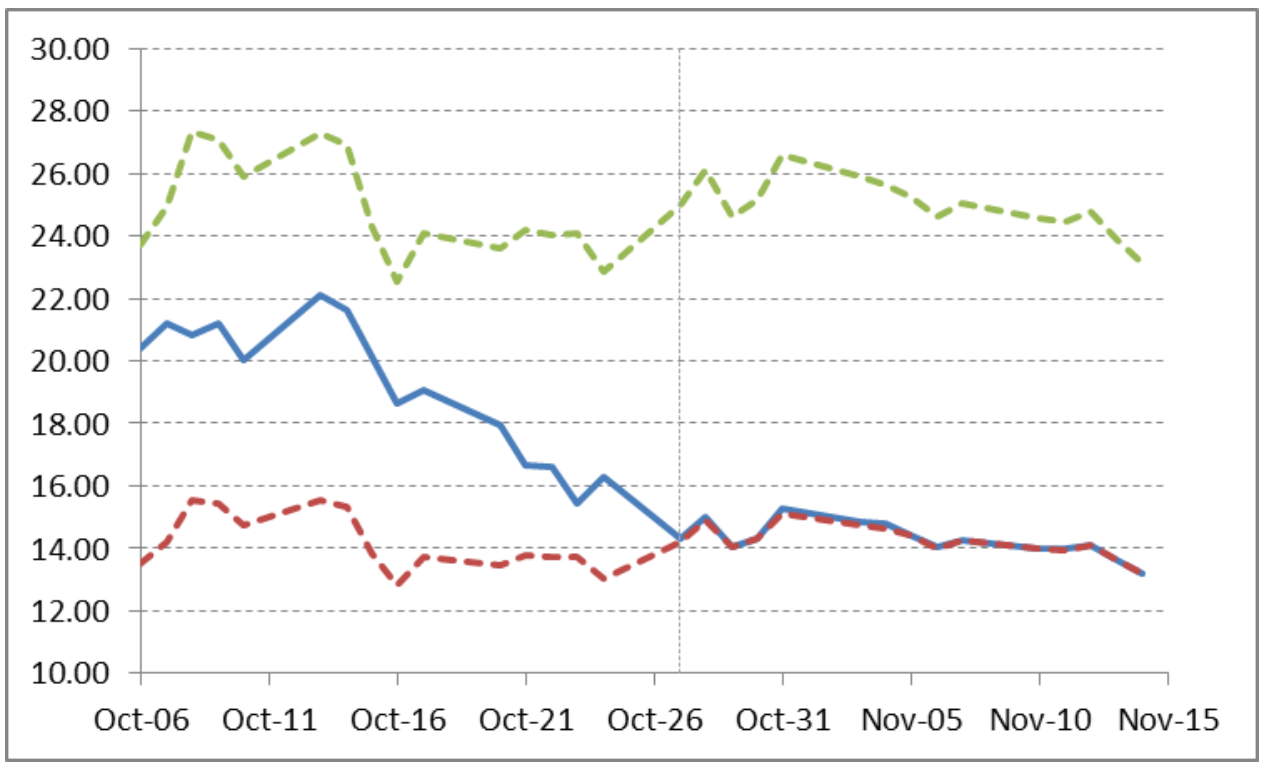

Figure 3: Estimated potential outcomes for Petrobras during the 2014 Brazilian presidential election, using the Black-Scholes diffusion model for $S_{l o w}(t)$. The solid line shows the observed price $S^{*}(t)$ and the dashed lines indicate the shadow prices $S_{\text {low }}(t)$ and $S_{\text {high }}(t)$. The dashed vertical line indicates the first trading day after Election Day.

\subsubsection{Black and Scholes with an election-day jump}

In order to allow for uncertainty about the effect of the election on the price of Petrobras, this case adds to the Black and Scholes diffusion process in (5) a stochastic jump on election day. We assume the jump follows a log-normal distribution, with 0 mean and standard deviation $\zeta$. Hence, for options traded before the election, this model is a version of the model in Merton (1976) where it is known there will be one jump. The formula for $\tilde{C}$ is thus the Black and Scholes option-pricing formula with variance $\sigma^{2}+\zeta^{2} / \tau$ (instead of $\sigma^{2}$ ), where $\tau$ is the time to maturity (we refer to Merton (1976) for the derivation). For options traded after the election, the expression for $\tilde{C}$ is simply the Black and Scholes formula.

Besides a time series for $\theta(t)$ and $\Delta$, there are two parameters to be estimated, $\sigma$ and $\zeta$.

The estimates of $\Delta$ and parameters of the diffusion model are shown in Table 4 . The estimate of $\zeta$ is large, around 12\%, implying that the jump on Oct-27 was smaller than one standard deviation. Nevertheles, the estimate of $\Delta$ is very similar to the one in Table 2 . The estimate of $\sigma$ is in line with the volatility of Petrobras in normal times.

Table 10 in Appendix $D$ shows the estimates for the reelection probability $\theta(t)$ and the

appointed Minister of Finance. This could suggest a change in policies that affect Petrobras (including the 'Law of Local Content' and the control over oil prices) and thus would affect the valuation of Petrobras. 


\begin{tabular}{|c|c|c|}
\hline & estimate & std error \\
\hline$\Delta$ & $\mathbf{1 . 7 3 1}$ & 0.006 \\
$\sigma$ & 0.419 & 0.010 \\
$\zeta$ & 0.122 & 0.007 \\
\hline
\end{tabular}

Table 4: Estimated parameters of the extended version of the Black-Scholes model with an election-day jump.

implied shadow stock prices $S_{\text {high }}(t)$ and $S_{\text {low }}(t)$. The results are very similar to those reported in Table 3 ,

The bottom line of this Section is that uncertainty about $\Delta$ significantly affected option prices, but this has no important effect on the estimates of $\Delta$.

\subsubsection{The volatility smile}

One well known problem of the Black and Scholes model is that the implied tails of asset prices' probability distributions are too thin when compared to the data. This translates into a systematic relation between an option's implied volatility and its strike price.

In order to investigate this issue, we calculated the implied value of $\sigma$ for each option negotiated in the pre-election period. Using the estimated values of $\Delta$ and $\theta(t)$, we backed out a value of $\sigma$ that would yield each option price ${ }^{26}$

Figure 4 shows how the average value of the implied $\sigma$ 's vary with the strike price. Options were grouped in bins, corresponding to strike prices in the intervals $[10.75,11.24]$ ,[11.25, 11.74], [11.75, 12.24], and so on. Each point in the graph corresponds to the average implied $\sigma$ for options in a bin 27

Figure 4 shows there is indeed a systematic relation between strike prices and implied volatilities. This is a concern because it might bias the estimation of the parameters of interest $(\Delta$ and $\theta)$. The Black and Scholes model cannot account for the thickness of the tails of the asset distribution and this extra kurtosis might be affecting the estimated values of $\Delta$ and $\theta$. We thus move to the Heston model.

\footnotetext{
${ }^{26}$ We employed the estimates of $\Delta$ and $\theta(t)$ shown in Tables 2 and 3 , but the result is basically the same if we employ the estimates from Section 4.1.1. We used the pre-election period only because high-strike options are worth almost zero after the election.

${ }^{27}$ In cases the theoretical option price was larger than the observed price for any positive volatility, we considered the implied $\sigma$ for the option was zero.
} 


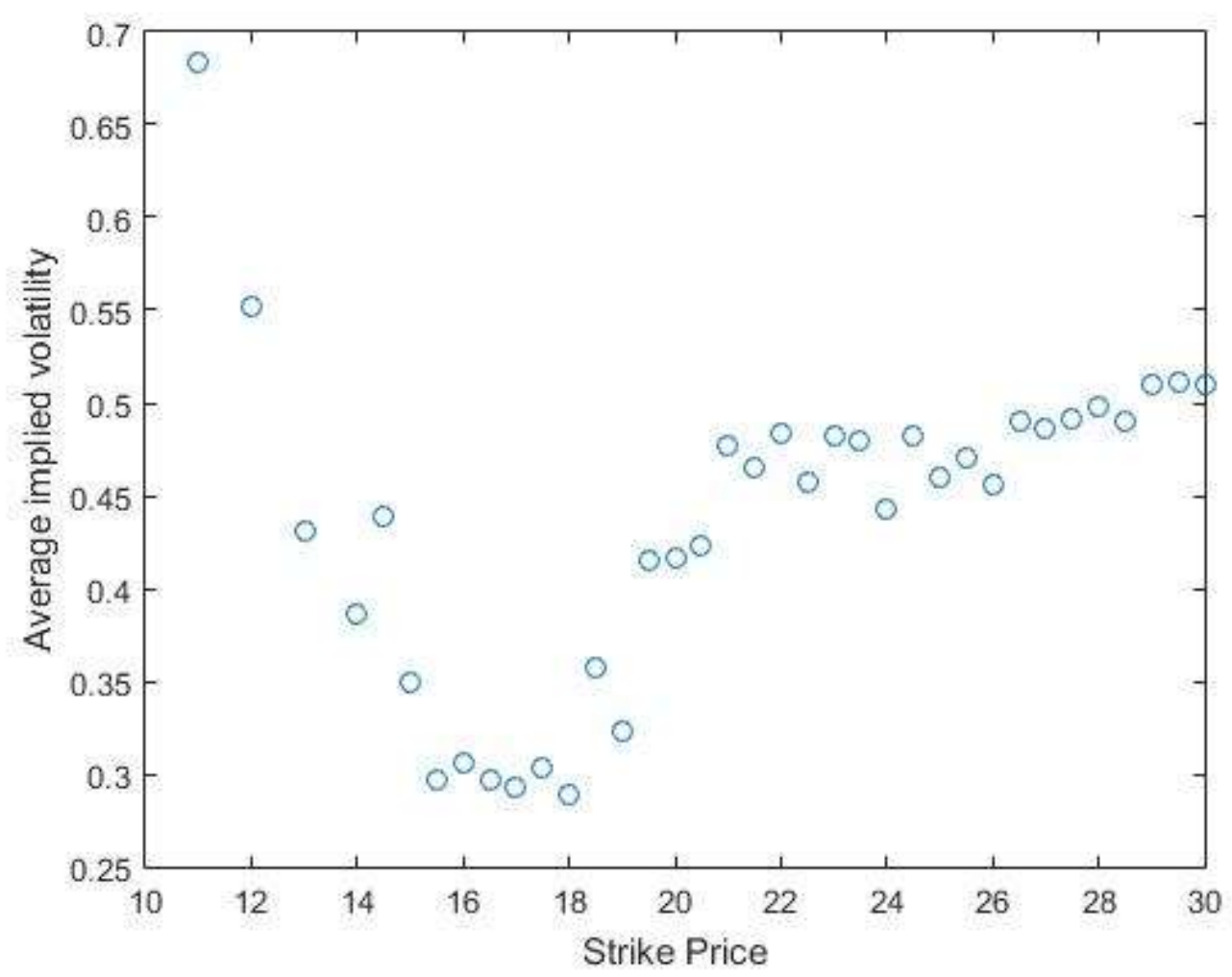

Figure 4: Average implied volatility of each option negotiated between October-6 and October-24, in case $S_{\text {low }}(t)$ follows the Black-Scholes diffusion model, using the estimated values of $\Delta$ and $\theta(t)$.

\subsection{The Heston model}

While the Black-Scholes model is a common benchmark for option pricing, the assumption of a constant volatility is strong and unlikely to hold in practice. The model of Heston (1993) allows for stochastic volatility: volatility itself is assumed to follow a diffusion process. Instead of the diffusion in (5), we then have:

$$
\frac{d S_{\text {low }}(t)}{S_{\text {low }}(t)}=\mu d t+\sqrt{v(t)} d W_{1 t},
$$

and

$$
d v(t)=\kappa(\alpha-v(t)) d t+\xi \sqrt{v(t)} d W_{2 t},
$$

where $\kappa, \alpha$ and $\xi$ are positive parameters, $d W_{1 t}$ and $d W_{2 t}$ are Wiener processes and the correlation between them is $\rho$. The Heston model yields a closed form solution for option prices (we refer to the original paper for the formulae), which is the formula for $\tilde{C}$ in this 
case.

Besides a time series for $\theta(t)$ and $\Delta$, option prices depend on a time series for the volatility $v(t)$ and five other parameters: $\alpha$, the long run value of $v(t) ; \kappa$, the speed of mean reversion; $\xi$, the variance in the process for the volatility $v(t) ; \rho$, the correlation between both Wiener processes; and $\lambda$, the price of volatility.

In principle, one could estimate $\Delta$, the five parameters from the Heston model and a time series for $v$ and $\theta$. However, our data is not able to identify all parameters of the Heston model. In particular, the standard errors for $\alpha$ and $\lambda$ were always very large. We thus set the price of volatility $\lambda$ to zero and $\alpha$, the long run variance of changes in the asset price, was set to match the estimate of $\sigma$ in Table 2. Importantly, the estimate of $\Delta$ is not at all sensitive to this choice.

We thus estimate three parameters of the Heston model $(\kappa, \xi$ and $\rho), \Delta$ and a time series for $\theta(t)$ and $v(t)$. Since we are estimating daily values of $v(t)$ with no restrictions, adding an election-day jump as in Section 4.1.1 would be redundant.

Table 5 shows the estimates for $\Delta$ and the remaining parameters of the Heston model $(\kappa$, $\delta$ and $\rho$ ).

\begin{tabular}{|c|c|c|}
\hline & estimate & std error \\
\hline$\Delta$ & $\mathbf{1 . 6 6 1}$ & 0.006 \\
\hline$\kappa$ & 3.89 & 3.77 \\
\hline$\xi$ & 5.03 & 1.15 \\
\hline$\rho$ & -0.312 & 0.03 \\
\hline
\end{tabular}

Table 5: Estimated valuation gap and parameters of the Heston model

The estimate for $\Delta$ is 1.66. This is somewhat smaller than the estimate found in Section 4.1. but still huge. Intuitively, in the Heston model, the tails of the probability distribution of the underlying asset are thicker, which raises the price of out-of-the-money options. That is compensated by a lower $\Delta$, since it leads to lower prices of out-of-the-money options.

This result implies that preference shares of Petrobras would be worth BRL 25.09, or around 66\% more had Ms Rousseff lost the election. Using the results in Appendix B to estimate the counterfactual ratio of the preference share price to the ordinary share price, we estimate that ordinary shares of Petrobras would be worth BRL 22.02, or around $58 \%$ more in case of an opposition victory.

According to these estimates, an opposition victory would have raised the value of the 
company by USD 44.7 billion (BRL 113.2 billion). Petrobras would be worth around $62 \%$ more if Ms. Rousseff had lost the election. This figure corresponds to around $1.85 \%$ of Brazilian GDP or around 5\% of the market capitalization of all listed Brazilian companies in 2014.

\begin{tabular}{|c|c|c|c|c|c|c|c|}
\hline Date & $\theta$ & std error & $\mathrm{v}(\mathrm{t})$ & std error & $\mathrm{S}^{*}$ & $\mathrm{~S}^{\text {low }}$ & $\mathrm{S}^{\text {high }}$ \\
\hline Oct-06 & 0.56 & 0.010 & 0.18 & 0.029 & 20.39 & 15.80 & 26.25 \\
\hline Oct-07 & 0.55 & 0.010 & 0.20 & 0.025 & 21.21 & 16.38 & 27.21 \\
\hline Oct-08 & 0.53 & 0.015 & 0.53 & 0.090 & 20.85 & 15.89 & 26.40 \\
\hline Oct-09 & 0.45 & 0.019 & 0.59 & 0.103 & 21.20 & 15.58 & 25.88 \\
\hline Oct-10 & 0.49 & 0.017 & 0.57 & 0.097 & 20.02 & 14.95 & 24.84 \\
\hline Oct-13 & 0.39 & 0.017 & 0.52 & 0.079 & 22.13 & 15.80 & 26.25 \\
\hline Oct-14 & 0.42 & 0.016 & 0.51 & 0.075 & 21.65 & 15.62 & 25.95 \\
\hline Oct-15 & 0.55 & 0.010 & 0.23 & 0.023 & 20.15 & 15.52 & 25.78 \\
\hline Oct-16 & 0.56 & 0.010 & 0.20 & 0.026 & 18.65 & 14.47 & 24.04 \\
\hline Oct-17 & 0.58 & 0.011 & 0.27 & 0.027 & 19.09 & 14.91 & 24.77 \\
\hline Oct-20 & 0.57 & 0.014 & 0.45 & 0.056 & 17.92 & 13.92 & 23.12 \\
\hline Oct-21 & 0.70 & 0.013 & 0.44 & 0.056 & 16.68 & 13.90 & 23.09 \\
\hline Oct-22 & 0.70 & 0.013 & 0.47 & 0.061 & 16.61 & 13.87 & 23.05 \\
\hline Oct-23 & 0.86 & 0.015 & 0.58 & 0.103 & 15.41 & 14.09 & 23.41 \\
\hline Oct-24 & 0.68 & 0.017 & 0.66 & 0.091 & 16.30 & 13.44 & 22.34 \\
\hline Oct-27 & 0.99 & 0.005 & 0.32 & 0.049 & 14.29 & 14.24 & 23.66 \\
\hline Oct-28 & 0.98 & 0.005 & 0.22 & 0.033 & 15.03 & 14.80 & 24.59 \\
\hline Oct-29 & 1.00 & 0.005 & 0.25 & 0.042 & 14.02 & 14.02 & 23.29 \\
\hline Oct-30 & 1.00 & 0.005 & 0.25 & 0.039 & 14.32 & 14.30 & 23.75 \\
\hline Oct-31 & 0.97 & 0.005 & 0.18 & 0.029 & 15.28 & 15.01 & 24.94 \\
\hline Nov-03 & 0.98 & 0.005 & 0.23 & 0.036 & 14.85 & 14.68 & 24.39 \\
\hline Nov-04 & 0.97 & 0.004 & 0.20 & 0.036 & 14.82 & 14.55 & 24.17 \\
\hline Nov-05 & 1.00 & 0.005 & 0.24 & 0.040 & 14.40 & 14.38 & 23.89 \\
\hline Nov-06 & 0.99 & 0.005 & 0.22 & 0.042 & 14.06 & 13.98 & 23.23 \\
\hline Nov-07 & 1.00 & 0.004 & 0.19 & 0.039 & 14.27 & 14.27 & 23.71 \\
\hline Nov-10 & 1.00 & 0.004 & 0.25 & 0.053 & 13.98 & 13.98 & 23.23 \\
\hline Nov-11 & 0.99 & 0.004 & 0.11 & 0.045 & 14.00 & 13.88 & 23.06 \\
\hline Nov-12 & 1.00 & 0.004 & 0.18 & 0.055 & 14.11 & 14.11 & 23.44 \\
\hline Nov-13 & 1.00 & 0.004 & 0.19 & 0.069 & 13.60 & 13.60 & 22.60 \\
\hline Nov-14 & 1.00 & 0.004 & 0.06 & 0.070 & 13.20 & 13.16 & 21.87 \\
\hline & & & & & & & \\
\hline
\end{tabular}

Table 6: Estimated market probability of Dilma's reelection and volatilities, using the Heston diffusion model for $S_{\text {low }}(t)$ 
The results for the probability of reelection $\theta(t)$ and volatility $v(t)$ are presented in Table 6 . Figure 5 shows the estimates for $\theta(t)$. The path of the probability of reelection is similar to the one found in Section 4.1. The main difference is in the first two days of the sample: here, the reelection probability is around 55\% as opposed to around 35\% in the Black and Scholes case. As before, the estimates for $\theta$ between Oct- 6 and Oct-20 are between 0.40 and 0.60. The reelection probability reaches $86 \%$ on Oct-23, getting back to $68 \%$ on Oct-24, right before the election.

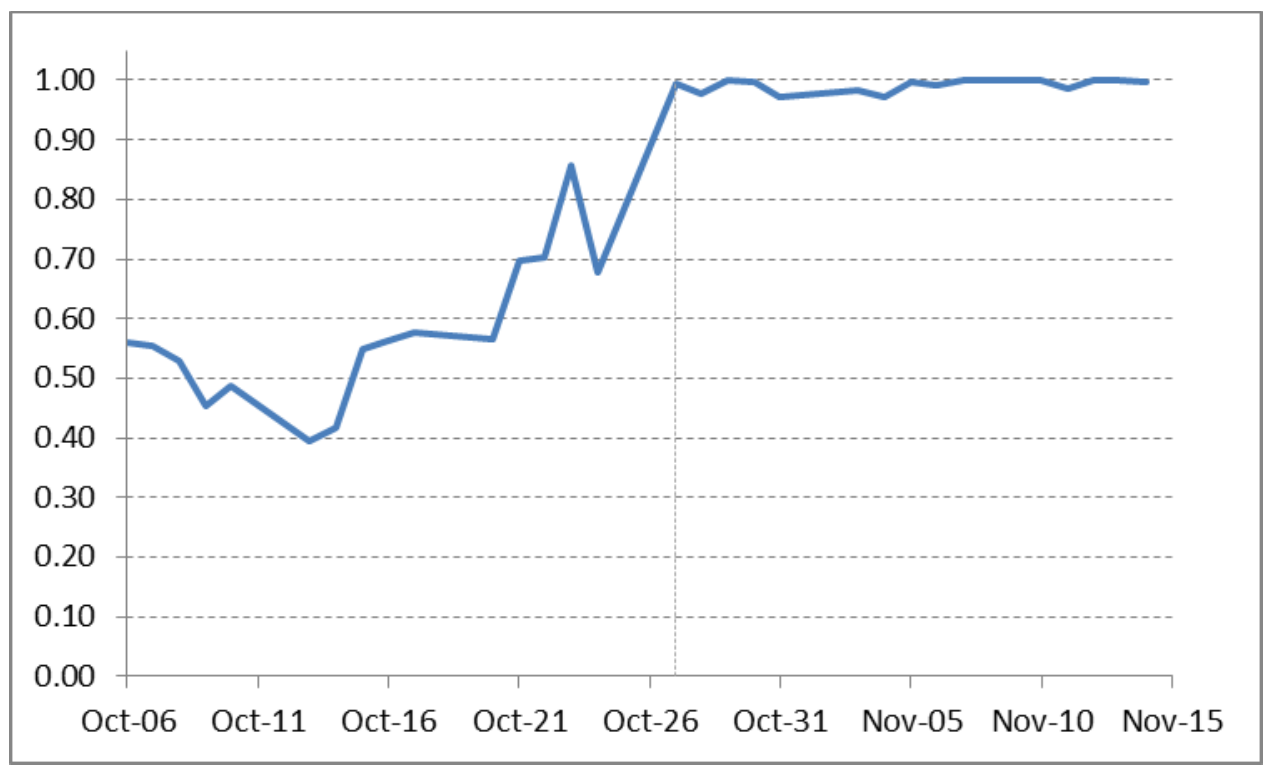

Figure 5: Estimated market probability of Ms. Rousseff's reelection, using the Heston diffusion model for $S_{l o w}(t)$. The dashed vertical line indicates the first trading day after Election Day.

Figure 6 shows the observed price of Petrobras shares and the shadow prices $S_{l o w}(t)$ and $S_{\text {high }}(t)$. The paths of $S_{\text {low }}(t)$ and $S_{\text {high }}(t)$ are very smooth when compared to their counterparts in Section 4.1 .

The shadow price of Petrobras in the Low state falls from around BRL 16 in the first days of the sample to around BRL 14 right before the election. This is a large drop, but oil prices went down by about $10 \%$ in this period. ${ }^{28}$ The changes in $S_{l o w}(t)$ appear to be small in Figure 6 only because the observed asset price $S^{*}(t)$ falls by much more owing to the increase in the reelection probability in this period. Note that $S_{\text {low }}(t)$ on Oct-24 was larger than previous estimates (BRL 13.44 instead of BRL 13.01 and BRL 13.12).

\footnotetext{
${ }^{28}$ Data from http://www.investing.com/commodities/crude-oil-historical-data.
} 




Figure 6: Estimated potential outcomes for Petrobras during the 2014 Brazilian presidential election, using the Heston diffusion model for $S_{\text {low }}(t)$. The solid line shows the observed price $S^{*}(t)$ and the dashed lines indicate the shadow prices $S_{l o w}(t)$ and $S_{h i g h}(t)$. The dashed vertical line indicates the first trading day after Election Day.

\subsubsection{Implied volatility and strike prices}

We now repeat the exercise of Section 4.1.2 using the results from our extension of the Heston model. We calculate the implied value of $v(t)$ for each option negotiated in the pre-election period using the estimates of the Heston model shown in tables 6 and 5 (with the exception of the volatility $v(t))$. As before, options were grouped in bins, corresponding to strike prices in the intervals $[10.75,11.24],[11.25,11.74],[11.75,12.24]$, and so on. Figure 7 shows the average value of the implied $\sigma$ for options in each bin.

Although there seems to be a lot of noise in the prices of low-strike-price options, there is no evident systematic relationship between the strike price and the implied volatility. ${ }^{29}$ The Heston model seems to be able to capture the excess kurtosis of the asset price distribution. For this reason, this is our preferred specification.

\section{$5 \quad$ The effect of the election on other asset prices}

The lack of available data on options with many different strike prices for companies other than Petrobras prevents us from extending our estimation to a wider set of firms. However,

\footnotetext{
${ }^{29}$ As shown in Table 1 options with strike prices below 13.16 were not very liquid before the election.
} 


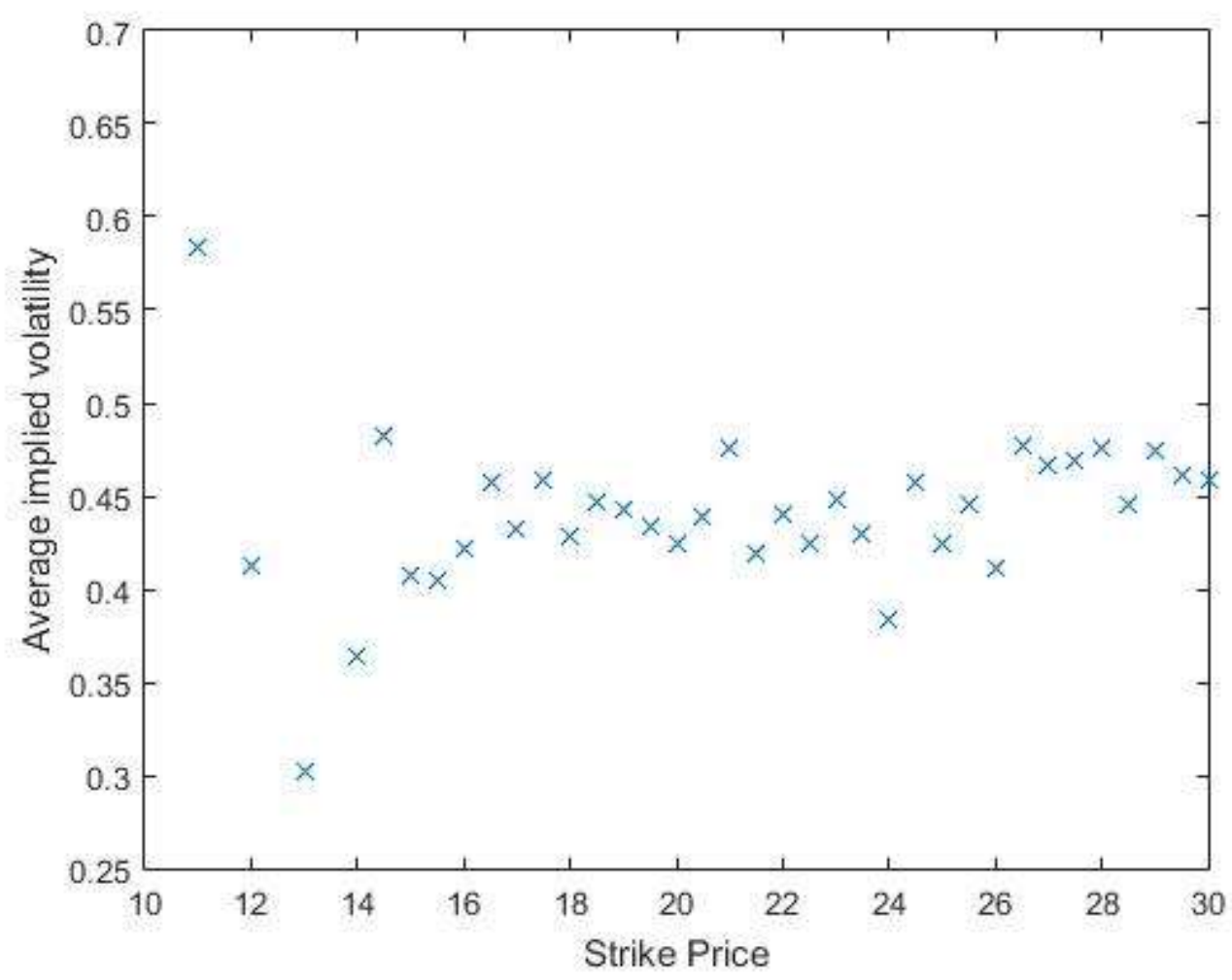

Figure 7: The average implied volatility of each option negotiated between October-6 and October-24, in case $S_{l o w}(t)$ follows the Heston diffusion model, using the estimates for $\Delta, \theta(t)$ and parameters of the Heston model.

our estimates of reelection probabilities can be used to assess the impact of Ms. Rousseff's reelection on other asset prices. We now estimate the effect of the election on the 20 most traded shares in the Brazilian stock market and on the exchange rate.

From (1), we obtain

$$
\log \left(S^{*}(t)\right)=\log \left[S_{\text {low }}(t)\right]+\log [\theta(t)+(1-\theta(t)) \Delta]
$$

where $\Delta$ is the effect on the asset price of a victory by Mr. Neves. Taking first differences and assuming that $\varepsilon(t)=\log \left(S_{\text {low }}(t)\right)-\log \left(S_{\text {low }}(t-1)\right)$ is a mean-zero error term, we get that

$$
\log \left(\frac{S^{*}(t)}{S^{*}(t-1)}\right)=\log \left(\frac{\theta(t)+(1-\theta(t)) \Delta}{\theta(t-1)+(1-\theta(t-1)) \Delta}\right)+\varepsilon(t)
$$

Using (6), the estimates for the probability of reelection $\theta(t)$ from Table 6 and daily data on 
asset prices, we estimate $\Delta$, for each asset, by non linear least squares. For consistency with the option data, we use the closing price of each asset.

From October-6 to October-27, we have only 15 data points. Asset prices on October27, the Monday following the election, are affected by news about the plans of the reelected president, which are not captured by our option data, so we also estimate the model using data until Friday October-24 (which leaves us with 14 data points). Moreover, our measures of $\theta(t)$ are subject to some error, so our estimator of $\Delta$ might suffer from attenuation bias.

Nevertheless, we find some strong and significant effects of reelection on asset prices. Table 7 shows the estimates for $\Delta$.

The estimates show that Ms. Rousseff's reelection had a strong negative impact in many companies. The effects are particularly strong in the banking sector, but also seem to be important for a variety of firms, including BM\&F Bovespa (the stock exchange), CBD (supermarkets), Ultrapar (fuel distribution) and Ambev (beer). The only possible exception is Embraer, the Brazilian aircraft manufacturer. The effects are also large in absolute terms, perhaps around USD 15 billion for Itau and USD 10 billion for Banco do Brasil, Bradesco and Ambev ${ }^{30}$ Moreover, the Brazilian currency is estimated to have lost around $7 \%$ of its value owing to Ms. Rousseff's reelection.

However, the estimated effects on private companies are never as strong as the effects on Petrobras. Interestingly, the company that seems to be mostly affected by the election, besides Petrobras, is Banco do Brasil, the Brazilian state bank. The estimates of $\Delta$ are very large, 1.31 or 1.45 , depending on whether October-27 is included in the sample. While the magnitude might sound surprising, some effect was indeed expected. In 2012, Ms. Rousseff grabbed the headlines by coaxing Banco do Brasil (and other state banks) to reduce interest rates to borrowers 41 This is a clear example of a state-owned firm focusing on objetives other than maximizing profits. The result is thus consistent with the idea that state-controlled firms are particularly vulnerable to political risk.

The estimated $\Delta$ for preferred shares of Petrobras (PETR4) is 1.45 or 1.50, depending on whether data from October-27 is included in the sample. Using data on options, the estimated $\Delta$ is 1.66 in our preferred specification (Table 5). This is well inside the $90 \%$-confidence interval for $\Delta$ estimated in this Section using data until October-24, but the difference is substantial ${ }^{32}$ We conjecture that attenuation bias might be affecting our estimates. Still, the

\footnotetext{
${ }^{30}$ Using the number of outstanding preference and ordinary shares and their prices on October 27, Itau, Banco do Brasil, Bradesco and Ambev would be worth 60.4, 23.8, 37.0 and 90.6 billion dollars respectively.

${ }^{31}$ State banks' interest rate cuts affected private banks, who had to reduce their lending rates as well. Hence the large estimated effects of reelection on the value of private banks might be partially explained by the effect of government actions on Banco do Brasil.

${ }^{32}$ Data until October-27 includes post-election information that is not considered by our option-based estimation. As discussed in Section 4.1 on October-27, markets seemed less pessimistic than expected, so our estimate using data until October-27 should
} 


\begin{tabular}{|c|c|c|c|c|c|c|c|c|}
\hline & & & \multicolumn{3}{|c|}{ Oct-6 to 0ct-27 } & \multicolumn{3}{|c|}{ Oct- 6 to 0 ct- 24} \\
\hline & & & \multirow[t]{2}{*}{$\Delta$} & \multicolumn{2}{|r|}{ std error } & \multirow[t]{2}{*}{$\Delta$} & \multicolumn{2}{|r|}{ std error } \\
\hline \multicolumn{3}{|c|}{ State-controlled companies } & & & & & & \\
\hline PETR4 & Petrobras & Oil & 1.453 & $* * *$ & 0.081 & 1.495 & $* * *$ & 0.116 \\
\hline PETR3 & Petrobras & Oil & 1.403 & $* * *$ & 0.080 & 1.431 & $* * *$ & 0.116 \\
\hline BBAS3 & Banco do Brasil & Banking & 1.313 & $* * *$ & 0.082 & 1.451 & $* * *$ & 0.105 \\
\hline BBSE3 & BB Seguridade & Insurance & 1.019 & & 0.037 & 1.088 & $*$ & 0.047 \\
\hline \multicolumn{3}{|c|}{ Private-controlled companies } & & & & & & \\
\hline BVMF3 & BM\&F Bovespa & Finance & 1.237 & $* * *$ & 0.079 & 1.398 & $* * *$ & 0.095 \\
\hline BBDC4 & Bradesco & Banking & 1.213 & $* * *$ & 0.067 & 1.350 & $* * *$ & 0.081 \\
\hline ITUB4 & Itaú & Banking & 1.211 & $* * *$ & 0.056 & 1.307 & $* * *$ & 0.071 \\
\hline BBDC3 & Bradesco & Banking & 1.209 & $* * *$ & 0.058 & 1.272 & $* * *$ & 0.081 \\
\hline ITSA4 & Itaú (holding) & Banking & 1.191 & $* * *$ & 0.056 & 1.286 & $* * *$ & 0.071 \\
\hline PCAR4 & CBD & Retail & 1.140 & $* * *$ & 0.038 & 1.154 & $* *$ & 0.054 \\
\hline UGPA3 & Ultrapar & Fuels & 1.108 & $* *$ & 0.045 & 1.177 & $* *$ & 0.059 \\
\hline JBSS3 & $\mathrm{JBS}$ & Food & 1.108 & $*$ & 0.059 & 1.183 & $* *$ & 0.080 \\
\hline ABEV3 & Ambev & Beverages & 1.085 & $* *$ & 0.037 & 1.154 & $* * *$ & 0.045 \\
\hline CCRO3 & CCR & Construction & 1.076 & & 0.069 & 1.249 & $* * *$ & 0.072 \\
\hline VALE5 & Vale & Mining & 1.071 & & 0.047 & 1.006 & & 0.063 \\
\hline VALE3 & Vale & Mining & 1.062 & & 0.047 & 0.999 & & 0.064 \\
\hline BRFS3 & $\mathrm{BRF}$ & Food & 1.054 & & 0.040 & 1.102 & $*$ & 0.054 \\
\hline CIEL3 & Cielo & Finance & 0.990 & & 0.070 & 1.090 & & 0.093 \\
\hline KROT3 & Kroton & Education & 0.967 & & 0.063 & 1.161 & $* * *$ & 0.048 \\
\hline EMBR3 & Embraer & Airplanes & 0.914 & $*$ & 0.047 & 0.930 & & 0.068 \\
\hline \multicolumn{3}{|c|}{ Currency } & & & & & & \\
\hline USDBRL & Real/Dollar & & 0.933 & $* * *$ & 0.021 & 0.926 & $* *$ & 0.030 \\
\hline
\end{tabular}

Table 7: Estimates of $\Delta$ via non-linear least squares, from (6). The values of $\theta(t)$ are taken from Table 6 . The signs $* * *, * *$ and $*$ indicate rejection of the null hypothesis $H_{0}: \Delta=1$ at the levels of significance $1 \%$, $5 \%$ and $10 \%$, respectively. For some companies, both preferred and ordinary shares made it into the top 20 most traded shares in the Brazilian stock market, so both appear in the list.

results in Table 7 agree with the hypothesis that an opposition win would have had a large effect on asset prices and that it would have been particularly important for state-controlled companies.

indeed be smaller than the results from Section 4 


\section{Concluding remarks}

This paper proposes an extension of standard asset diffusion models to study the effect on asset prices of the outcome of an election. Although our focus has been on presidential races, the model can be applied to other cases of anticipated events with binary outcomes.

The value of Petrobras shares is subject to huge political risk. Our preferred specification shows that Petrobras shares would be worth $62 \%$ more had Ms. Rousseff lost the presidential election. One implication of this paper is that the risk of de-facto expropriation of minority shareholders can be strongly affected not only by slow moving institutional factors but also by changes in government via elections.

\section{A The formula for the option price}

Under risk neutrality, the price of a call option with strike $K$, maturity $T$ and spot price $S_{t}^{*}$ is:

$$
C\left(S_{t}^{*}\right)=e^{-\int_{t}^{T} r_{u} d u} \mathbb{E}\left[S_{T}^{*}-K \mid S_{T}^{*} \geq K, I_{t}\right]
$$

The right-hand side of (1) can be rewritten as:

$$
\begin{aligned}
\mathbb{E}\left[S_{T}^{*}-K \mid S_{T}^{*} \geq K, I_{t}\right]= & \mathbb{E}\left[\theta(t) S_{\text {low }}+(1-\theta) \Delta S_{\text {low }}-K \mid S_{T}^{*} \geq K, I_{t}\right] \\
=\mathbb{E}\left[\theta(t)\left(S_{\text {low }}-K\right) \mid S_{T}^{*} \geq K, I_{t}\right]+ & \\
& +\mathbb{E}\left[(1-\theta(t))\left(\Delta S_{\text {low }}-K\right) \mid S_{T}^{*} \geq K, I_{t}\right]
\end{aligned}
$$

The assumption that the election outcome (shocks to $\theta(t)$ ) and shocks to $S_{\text {low }}$ are uncorrelated implies that

$$
\mathbb{E}\left[\theta(t)\left(S_{\text {low }}-K\right) \mid S_{T}^{*} \geq K, I_{t}\right]=\theta(t) \mathbb{E}\left[\left(S_{\text {low }}-K\right) \mid S_{T}^{*} \geq K, I_{t}\right]
$$

and

$$
\mathbb{E}\left[(1-\theta(t))\left(\Delta S_{\text {low }}-K\right) \mid S_{T}^{*} \geq K, I_{t}\right]=(1-\theta(t)) \mathbb{E}\left[\left(\Delta S_{\text {low }}-K\right) \mid S_{T}^{*} \geq K, I_{t}\right]
$$

Since $\mathbb{E}\left[\left(S_{\text {low }}-K\right) \mid S_{T}^{*} \geq K, I_{t}\right]=C_{b s}\left(S_{\text {low }}(t)\right)$ and $\mathbb{E}\left[\left(\Delta S_{\text {low }}-K\right) \mid S_{T}^{*} \geq K, I_{t}\right]=C_{b s}\left(S_{\text {high }}(t)\right)$, we get the expression in (2). 


\section{B The gap in prices of ordinary shares}

Our estimates show that preference shares of Petrobras would cost 66\%-75\% more had the opposition won the election. If the relation between prices of preference and ordinary shares were unaffected by the election result, we could use these numbers to estimate the effect of the election on the value of Petrobras. However, as shown in Table 8, the ratio of the preference share price to the ordinary share price appears to vary systematically with the probability of reelection: a larger $\theta$ is associated with a lower ratio 33

A simple linear regression of the ratio of the preference share price to the ordinary share price on the probability of reelection $\theta$ yields a ratio equal to 1.0783 at the point $\theta=0$. We employ this number to estimate the counterfactual price of ordinary shares.

The counterfactual preference share prices are obtained by multiplying the closing price on October-27 (BRL 14.29) by the estimates of $\Delta$. This yields share prices equal to BRL 25.09 using the estimates from Table 2 and BRL 23.74 using the estimates from Table 5. Dividing these prices by the estimate of the ratio (1.0783) yields the estimated counterfactual ordinary share prices, 23.26 and 22.02, respectively. The estimated counterfactual value of Petrobras is then found by attributing the estimated counterfactual prices to the 5.6 billion outstanding preference shares and 7.44 billion ordinary shares.

\section{Robustness}

\section{C.1 Daily estimates of $\Delta$}

We estimate the model based on the Black and Scholes diffusion process allowing for a different $\Delta$ at every date and imposing no relation between them. Although the variables that affect $\Delta$ are expected to move slowly, it is plausible that voters' perceptions about each candidates effect on Petrobras could change significantly in the days or weeks preceding the election. The results are shown in Table 9. The estimate of $\sigma$ is $41.2 \%$.

Figure 8 shows the estimates for the valuation gap. The estimates for $\Delta_{t}$ vary between 1.64 and 1.86. The average estimate is 1.75 , which is very close to what we obtained in Section 4 .

The path of the probability of reelection $\theta(t)$ is similar to the obtained using the Heston model in Section 4.2. The general message is that the probability of reelection oscillates around half until October $20^{\text {th }}$ and then goes up to $70 \%-80 \%$.

Although the estimates of $\Delta$ vary in time, there is no clear trend. Overall, allowing $\Delta$ to vary every day yields estimates very similar to the baseline results.

\footnotetext{
${ }^{33}$ We don't have estimates of the probability of reelection for a longer period of time, but we also observe a positive relation between the price of Petrobras shares and this ratio right before the first ballot.
} 


\begin{tabular}{|c|c|c|c|c|}
\hline Date & Preference & Ordinary & ratio & $\theta$ \\
\hline Oct-06 & 20.39 & 19.20 & 1.062 & 0.56 \\
\hline Oct-07 & 21.21 & 19.95 & 1.063 & 0.55 \\
\hline Oct-08 & 20.85 & 19.58 & 1.065 & 0.53 \\
\hline Oct-09 & 21.20 & 19.96 & 1.062 & 0.45 \\
\hline Oct-10 & 20.02 & 18.87 & 1.061 & 0.49 \\
\hline Oct-13 & 22.13 & 20.75 & 1.067 & 0.39 \\
\hline Oct-14 & 21.65 & 20.42 & 1.060 & 0.42 \\
\hline Oct-15 & 20.15 & 19.02 & 1.059 & 0.55 \\
\hline Oct-16 & 18.65 & 17.64 & 1.057 & 0.56 \\
\hline Oct-17 & 19.09 & 18.18 & 1.050 & 0.58 \\
\hline Oct-20 & 17.92 & 17.12 & 1.047 & 0.57 \\
\hline Oct-21 & 16.68 & 16.19 & 1.030 & 0.70 \\
\hline Oct-22 & 16.61 & 16.05 & 1.035 & 0.70 \\
\hline Oct-23 & 15.41 & 15.05 & 1.024 & 0.86 \\
\hline Oct-24 & 16.30 & 15.70 & 1.038 & 0.68 \\
\hline Oct-27 & 14.29 & 13.92 & 1.027 & 1 \\
\hline Oct-28 & 15.03 & 14.51 & 1.036 & 1 \\
\hline Oct-29 & 14.02 & 13.53 & 1.036 & 1 \\
\hline Oct-30 & 14.32 & 13.78 & 1.039 & 1 \\
\hline Oct-31 & 15.28 & 14.65 & 1.043 & 1 \\
\hline Nov-03 & 14.85 & 14.25 & 1.042 & 1 \\
\hline Nov-04 & 14.82 & 14.25 & 1.040 & 1 \\
\hline Nov-05 & 14.40 & 13.86 & 1.039 & 1 \\
\hline Nov-06 & 14.06 & 13.55 & 1.038 & 1 \\
\hline Nov-07 & 14.27 & 13.77 & 1.036 & 1 \\
\hline Nov-10 & 13.98 & 13.41 & 1.043 & 1 \\
\hline Nov-11 & 14.00 & 13.49 & 1.038 & 1 \\
\hline Nov-12 & 14.11 & 13.54 & 1.042 & 1 \\
\hline Nov-13 & 13.60 & 13.13 & 1.036 & 1 \\
\hline Nov-14 & 13.20 & 12.78 & 1.033 & 1 \\
\hline
\end{tabular}

Table 8: Prices of preference and ordinary shares of Petrobras. The estimates of $\theta$ are those from Section 4.2 . From October-27 on, we use $\theta=1$. 


\begin{tabular}{|c|c|c|c|c|}
\hline Date & $\Delta$ & std error & $\theta$ & std error \\
\hline Oct-06 & 1.639 & 0.009 & 0.55 & 0.017 \\
\hline Oct-07 & 1.657 & 0.009 & 0.53 & 0.016 \\
\hline Oct-08 & 1.828 & 0.008 & 0.55 & 0.011 \\
\hline Oct-09 & 1.864 & 0.010 & 0.48 & 0.010 \\
\hline Oct-10 & 1.839 & 0.009 & 0.51 & 0.010 \\
\hline Oct-13 & 1.850 & 0.011 & 0.41 & 0.009 \\
\hline Oct-14 & 1.813 & 0.010 & 0.44 & 0.010 \\
\hline Oct-15 & 1.667 & 0.007 & 0.55 & 0.013 \\
\hline Oct-16 & 1.654 & 0.008 & 0.57 & 0.014 \\
\hline Oct-17 & 1.694 & 0.007 & 0.59 & 0.012 \\
\hline Oct-20 & 1.750 & 0.008 & 0.58 & 0.011 \\
\hline Oct-21 & 1.751 & 0.009 & 0.70 & 0.010 \\
\hline Oct-22 & 1.758 & 0.009 & 0.71 & 0.010 \\
\hline Oct-23 & 1.693 & 0.015 & 0.79 & 0.012 \\
\hline Oct-24 & 1.797 & 0.009 & 0.68 & 0.010 \\
\hline
\end{tabular}

Table 9: Daily estimates of reelection probabilities and valuation gaps, using the Black-Scholes diffusion model for $S_{\text {low }}(t)$.

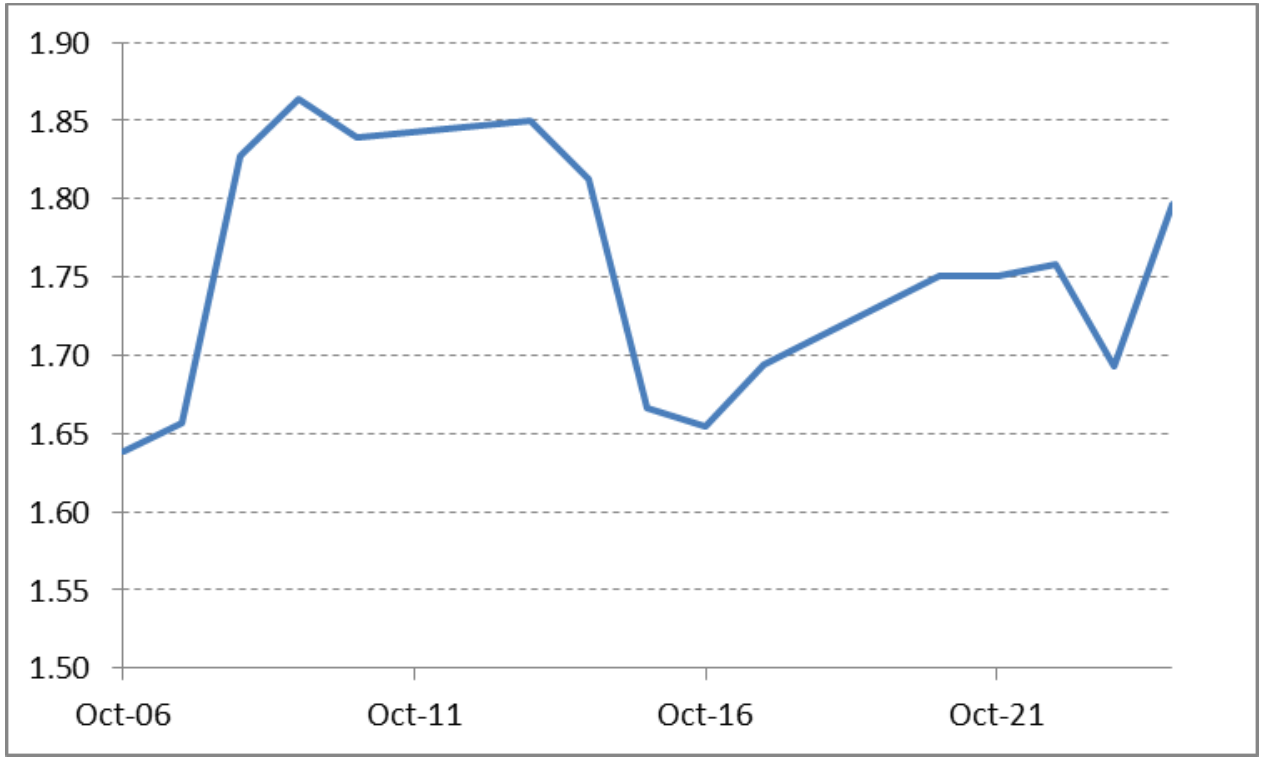

Figure 8: Estimated magnitude parameter $\Delta_{t}$ for each date 


\section{Table omitted from the text}

\begin{tabular}{|c|c|c|c|c|c|}
\hline Date & $\theta$ & std error & $\mathrm{S}^{*}$ & $\mathrm{~S}^{\text {low }}$ & $\mathrm{S}^{\text {high }}$ \\
\hline Oct-06 & 0.29 & 0.010 & 20.39 & 13.42 & 23.22 \\
\hline Oct-07 & 0.31 & 0.010 & 21.21 & 14.08 & 24.37 \\
\hline Oct-08 & 0.54 & 0.019 & 20.85 & 15.63 & 27.06 \\
\hline Oct-09 & 0.49 & 0.017 & 21.20 & 15.46 & 26.76 \\
\hline Oct-10 & 0.51 & 0.017 & 20.02 & 14.77 & 25.58 \\
\hline Oct-13 & 0.42 & 0.012 & 22.13 & 15.53 & 26.89 \\
\hline Oct-14 & 0.43 & 0.012 & 21.65 & 15.27 & 26.43 \\
\hline Oct-15 & 0.34 & 0.010 & 20.15 & 13.61 & 23.57 \\
\hline Oct-16 & 0.34 & 0.010 & 18.65 & 12.60 & 21.82 \\
\hline Oct-17 & 0.41 & 0.011 & 19.09 & 13.32 & 23.06 \\
\hline Oct-20 & 0.51 & 0.015 & 17.92 & 13.18 & 22.82 \\
\hline Oct-21 & 0.75 & 0.011 & 16.68 & 14.08 & 24.37 \\
\hline Oct-22 & 0.74 & 0.011 & 16.61 & 13.99 & 24.21 \\
\hline Oct-23 & 0.86 & 0.007 & 15.41 & 13.96 & 24.16 \\
\hline Oct-24 & 0.67 & 0.016 & 16.30 & 13.12 & 22.71 \\
\hline Oct-27 & 0.99 & 0.004 & 14.29 & 14.16 & 24.52 \\
\hline Oct-28 & 0.98 & 0.004 & 15.03 & 14.82 & 25.66 \\
\hline Oct-29 & 1.00 & 0.004 & 14.02 & 14.02 & 24.27 \\
\hline Oct-30 & 1.00 & 0.004 & 14.32 & 14.28 & 24.72 \\
\hline Oct-31 & 0.98 & 0.004 & 15.28 & 15.08 & 26.10 \\
\hline Nov-03 & 0.99 & 0.004 & 14.85 & 14.69 & 25.43 \\
\hline Nov-04 & 0.98 & 0.004 & 14.82 & 14.57 & 25.23 \\
\hline Nov-05 & 1.00 & 0.004 & 14.40 & 14.37 & 24.87 \\
\hline Nov-06 & 0.99 & 0.004 & 14.06 & 13.99 & 24.21 \\
\hline Nov-07 & 1.00 & 0.003 & 14.27 & 14.27 & 24.70 \\
\hline Nov-10 & 1.00 & 0.004 & 13.98 & 13.98 & 24.20 \\
\hline Nov-11 & 0.99 & 0.004 & 14.00 & 13.91 & 24.09 \\
\hline Nov-12 & 1.00 & 0.003 & 14.11 & 14.11 & 24.43 \\
\hline Nov-13 & 1.00 & 0.003 & 13.60 & 13.60 & 23.54 \\
\hline Nov-14 & 1.00 & 0.004 & 13.20 & 13.18 & 22.81 \\
\hline
\end{tabular}

Table 10: Estimated market probability of Ms. Rousseff's reelection, using the Black-Scholes model with an election-day jump for $S_{\text {low }}(t)$. 


\section{References}

Acemoglu, D., Hassan, T. and Tahoun, A. (2015). The power of the street: Evidence from Egypt's Arab Spring, Working Paper.

Aït-Sahalia, Y. and Lo, A. W. (1998). Nonparametric estimation of state-price densities implicit in financial asset prices, Journal of Finance 53(2): 499-547.

Baker, S. R., Bloom, N. and Davis, S. J. (2016). Measuring economic policy uncertainty, Quarterly Journal of Economics forthcoming.

Bakshi, G., Cao, C. and Chen, Z. (1997). Empirical performance of alternative option pricing models, Journal of Finance 52(5): 2003-2049.

Bates, D. S. (1991). The crash of'87: Was it expected? the evidence from options markets, Journal of Finance 46(3): 1009-1044.

Bates, D. S. (1996). Jumps and stochastic volatility: Exchange rate processes implicit in Deutsche Mark options, Review of Financial Studies 9(1): 69-107.

Bates, D. S. (2000). Post-'87 crash fears in the S\&P 500 futures option market, Journal of Econometrics 94(1): 181-238.

Beber, A. and Brandt, M. W. (2006). The effect of macroeconomic news on beliefs and preferences: Evidence from the options market, Journal of Monetary Economics 53(8): 19972039 .

Black, F. and Scholes, M. (1973). The pricing of options and corporate liabilities, Journal of Political Economy pp. 637-654.

Boardman, A. E. and Vining, A. R. (1989). Ownership and performance in competitive environments: A comparison of the performance of private, mixed, and state-owned enterprises, Journal of Law and Economics 32: 1-33.

Breeden, D. T. and Litzenberger, R. H. (1978). Prices of state-contingent claims implicit in option prices, Journal of Business 51(4): 621-651.

Brogaard, J. and Detzel, A. (2015). The asset-pricing implications of government economic policy uncertainty, Management Science 61(1): 3-18.

Calomiris, C. W., Fisman, R. and Wang, Y. (2010). Profiting from government stakes in a command economy: Evidence from Chinese asset sales, Journal of Financial Economics 96(3): 399-412. 
Campa, J. M. and Chang, P. H. K. (1996). Arbitrage-based tests of target-zone credibility: Evidence from ERM cross-rate options, American Economic Review 86(4): 726-740.

Campa, J. M., Chang, P. K. and Refalo, J. F. (2002). An options-based analysis of emerging market exchange rate expectations: Brazil's real plan, 1994-1999, Journal of Development Economics 69(1): 227-253.

Carvalho, D. (2014). The real effects of government-owned banks: Evidence from an emerging market, Journal of Finance 69(2): 577-609.

Claessens, S., Feijend, E. and Laeven, L. (2008). Political connections and preferential access to finance: The role of campaign contributions, Journal of Financial Economics 88(3): 554580.

Dewenter, K. L. and Malatesta, P. H. (2001). State-owned and privately owned firms: An empirical analysis of profitability, leverage, and labor intensity, American Economic Review 91(1): 320-334.

Dubinsky, A. and Johannes, M. (2006). Fundamental uncertainty, earning announcements and equity options, Working paper.

Faccio, M. (2006). Politically connected firms, American Economic Review 96(1): 369-386.

Faccio, M., Masulis, R. W. and McConnell, J. (2006). Political connections and corporate bailouts, Journal of Finance 61(6): 2597-2635.

Ferguson, T. and Voth, H.-J. (2008). Betting on Hitler: The value of political connections in Nazi Germany, Quarterly Journal of Economics 123(1): 101-137.

Fernandes, M. and Novaes, W. (2016). The government as a large shareholder: Impact on corporate governance, Working paper.

Ferraz, I. R. (2015). Mercado preditivo: um método de previsão baseado no conhecimento coletivo, PhD thesis, Universidade de São Paulo.

Fisman, R. (2001). Estimating the value of political connections, American Economic Review 91(4): 1095-1102.

Gemmill, G. (1992). Political risk and market efficiency: tests based in British stock and options markets in the 1987 election, Journal of Banking and Finance 16(1): 211-231.

Goodell, J. W. and Vähämaa, S. (2013). US presidential elections and implied volatility: The role of political uncertainty, Journal of Banking and Finance 37(3): 1108-1117. 
Gupta, N. (2005). Partial privatization and firm performance, Journal of Finance 60(2): 9871015.

Henry, P. B. and Miller, C. (2009). Institutions versus policies: A tale of two islands, American Economic Review 99(2): 261-267.

Herron, M. (2000). Estimating the economic impact of political party competition in the 1992 British election, American Journal of Political Science 44(2): 326-337.

Herron, M. C., Lavin, J., Cram, D. and Silver, J. (1999). Measurement of political effects in the united states economy: a study of the 1992 presidential election, Economics \& Politics 11(1): $51-81$.

Heston, S. L. (1993). A closed-form solution for options with stochastic volatility with applications to bond and currency options, Review of Financial Studies 6(2): 327-343.

Hull, J. and White, A. (1987). The pricing of options on assets with stochastic volatilities, Journal of Finance 42(2): 281-300.

Imai, M. and Shelton, C. A. (2011). Elections and political risk: New evidence from the 2008 Taiwanese presidential election, Journal of Public Economics 95(7-8): 837-849.

Johnson, S. and Mitton, T. (2003). Cronyism and capital controls: evidence from Malaysia, Journal of Financial Economics 67(2): 351-382.

Kelly, B., Pastor, L. and Veronesi, P. (2016). The price of political uncertainty: Theory and evidence from the option market, Journal of Finance forthcoming.

Knight, B. (2006). Are policy platforms capitalized into equity prices? Evidence from the Bush/Gore 2000 presidential election, Journal of Public Economics 90(4-5): 751-773.

La Porta, R. and Lopez-de Silanes, F. (1999). The benefits of privatization: Evidence from Mexico, Quarterly Journal of Economics 114(4): 1193-1242.

La Porta, R., Lopez-de Silanes, F., Shleifer, A. and Vishny, R. (2000). Investor protection and corporate governance, Journal of Financial Economics 58(1-2): 3-27.

La Porta, R., Lopez-de Silanes, F., Shleifer, A. and Vishny, R. (2002). Investor protection and corporate valuation, Journal of Finance 57(3): 1147-1170.

Leahy, M. and Thomas, C. (1996). The sovereignty option: the Quebec referendum and market views on the Canadian dollar, Working Paper. 
Leblang, D. and Mukherjee, B. (2005). Government partisanship, elections, and the stock market: examining American and British stock returns, 1930-2000, American Journal of Political Science 49(4): 780-802.

Leuz, C. and Oberholzer-Gee, F. (2006). Political relationships, global financing, and corporate transparency: Evidence from Indonesia, Journal of Financial Economics 81(2): 411439.

Malz, A. M. (1996). Using option prices to estimate realignment probabilities in the European Monetary System: the case of Sterling-Mark, Journal of International Money and Finance 15(5): $717-748$.

Megginson, W. L. and Netter, J. M. (2001). From state to market: A survey of empirical studies on privatization, Journal of Economic Literature 39(2): 321-389.

Melino, A. and Turnbull, S. M. (1990). Pricing foreign currency options with stochastic volatility, Journal of Econometrics 45(1): 239-265.

Merton, R. C. (1973). Theory of rational option pricing, Bell Journal of Economics and Management Science 4(1): 141-183.

Merton, R. C. (1976). Option pricing when underlying stock returns are discontinuous, Journal of Financial Economics 3(1-2): 125-144.

Pantzalis, C., Stangeland, D. A. and Turtle, H. J. (2000). Political elections and the resolution of uncertainty: the international evidence, Journal of Banking and Finance 24(10): 15751604.

Patell, J. and Wolfson, M. (1979). Anticipated information releases reflected in call option prices, Journal of Accounting and Economics 1: 117-140.

Santa-Clara, P. and Valkanov, R. (2003). The presidential puzzle: Political cycles and the stock market, Journal of Finance 58(5): 1841-1872.

Sapienza, P. (2004). The effects of government ownership on bank lending, Journal of Financial Economics 72(2): 357-384.

Snowberg, E., Wolfers, J. and Zitzewitz, E. (2007). Partisan impacts on the economy: evidence from prediction markets and close elections, Quarterly Journal of Economics 122(2): 807829.

Söderlind, P. and Svensson, L. (1997). New techniques to extract market expectations from financial instruments, Journal of Monetary Economics 40(2): 383-429. 